\title{
Wood resource management based on charcoals from the Bronze Age site of Gegharot (Central Armenia)
}

\author{
Fany Jude ${ }^{1}$, Dominique Marguerie ${ }^{1}$, Ruben Badalyan ${ }^{2}$, Adam T. Smith $^{3}$, Ann Delwaide ${ }^{4}$
}

1 Archeosciences Laboratory, UMR 6566 CReAAH, CNRS, University of Rennes 1, Beaulieu, 35052 Rennes cedex (France); fany.jude@gmail.com; dominique.marguerie@univrennes1.fr

${ }^{2}$ Department of Early Archaeology, Institute of Archaeology and Ethnography, National Academy of Sciences, 0025 Republic of Armenia, Yerevan, Charents Street 15; r.badalyan@yahoo.com

${ }^{3}$ Department of Anthropology, Cornell University, 261 McGraw Hall, Ithaca, NY 14853 (USA); ats73@cornell.edu

4 Department of Geography, Laval University, Québec (QC), G1V 0A6, Canada; ann.delwaide@cen.ulaval.ca

\section{Abstract:}

Excavations conducted at the site of Gegharot in north central Armenia, along the northeastern margin of the Tsaghkahovit Plain (Aragatsotn region) have produced a large quantity of well-preserved charcoals. With occupations dating to the Early and Late Bronze Age, the site has been excavated since 2000 under the supervision of R. Badalyan and A.T. Smith under the auspices of the joint Armenian-American Project ArAGATS. The examination of the wood anatomy along three sections under a reflected light microscope, necessary for the identifications of charcoals, was systematically undertaken completed with the observation of the ligneous structure on transverse sections using a stereomicroscope. This dendrological approach provides valuable data for aiding identification of which part of the tree used, recording growth ring width, estimating wood diameter, and ascertaining the state of the wood before carbonization.

Different vegetational biotopes were identified from remains of the Early Bronze Age layers at the site: an open woodland with heliophilic shrubs (birch, maple, willow and Pomoïdeae), an open forest formation with notably oak with maple and ash trees and a wet zone with willows and ash trees. The estimated diameters of the wood used at that time did not exceed $12 \mathrm{~cm}$. The wood collection from the Late Bronze Age levels indicates a pine and oak forest surrounded by open areas where birch trees and Pomoïdeae grew and wetlands with willow 
trees and elm as riparian forests. The onset of a colder and drier climate could be the cause of the disappearance of the ash trees, the appearance of oak pine forests and the reduced growth of the tree-ring width. The taxa list and the high frequency of the small diameters observed during both occupations can refer to a local woodland exploitation. According to the observation of the last ring before the bark, evidence from a single operation (T21), during the Late Bronze Age testifies to seasonal activities. Some large charcoals of pine or oak had exceptional long series of more than 60 tree-rings. The average curve built on the basis of the oak series has a length of 72 rings, the beginning of a tree-ring series building in Armenia for the Bronze Age.

Keywords: Human impact, Climate, Charcoal, Tree-ring, Bronze Age, Armenia

\section{Introduction}

The Bronze Age in Armenia witnessed dramatic changes in the culture, economy, and society of human communities. Changes in the social landscape during this period are welldocumented; on the other hand the environmental landscape itself is currently poorly understood. Anthracological studies from archaeological settlements are rare in the territory of Armenia. The analysis of Bronze Age charcoals from the site of Gegharot that we present here is the first systematic, large-scale application of this technique in Armenia. Two anthracological analyses were recorded in Neolithic settlements in the Ararat Plain. The first, focused on the site of Aratashen, was conducted by H. Pessin (Badalyan et al., 2007); the second, focused on the nearby settlement of Akhnashen-Khatunarkh, was conducted by R. Hovsepyan (Badalyan et al., 2010a). Pollen analyses including the Bronze Age period are sparse. Several studies have been conducted in the Sevan Lake area, including, on the eastern (Norashen; Sayadyan, 1978), south-eastern (valley of the Masrik river; Takhtajyan, 1941), western (valley of the Gavaraget river; Sayadyan, 1983) and, most recently southern shores (Vanevan, $1926 \mathrm{~m}$ a.s.l.; Leroyer et al., in press). Another recent palynological study encompassing the Bronze Age was undertaken at the Zarishat marsh, situated on the Djavakheti Plateau at $2116 \mathrm{~m}$ a.s.l. (Joannin et al., 2013). The plant remains of the Early Bronze Age from Gegharot, Aparan-III, and Tsaghkasar-I, in the Mt. Aragats region, have been extensively studied (Hovsepyan, 2010).

Charcoals from archaeological settlements are linked to woodland exploitation mainly for fuel or timber needs. This woodland exploitation is related to environmental capacities. Thus, charcoals analyses can help to reconstruct nearby woodlands through comparisons between the current local woodland and the results of the anthracological analyses in order to interpret 
climate regimes and potential human impacts (Marson, 2009; Chabal, 1997; Willcox, 2002). In Armenia, understanding past woodland environments is important not only for an understanding of past economies but also in order to understand how vegetation has changed over time in relation to human activities, such as desertification caused by deforestation and over-grazing (Moreno-Sanchez and Sayadyan, 2005). The principal goals of this study will be to (1) reconstruct the different stages (over time) of the Bronze Age environment, (2) highlight the impact of climate on the environment in order to provide fundamental climate and environmental studies resources. It will thus be possible to approach (3) the interaction between the high-elevation vegetation resources and the human woodland exploitation.

\section{Current vegetation and physical setting}

Modern Armenia encompasses a land-locked, mountainous portion of the South Caucasus region. The regional climate today is arid and continental with considerable fluctuations in annual and sometimes daily temperatures. The complex relief of the region creates a vertical zonal climate. Annual precipitation fluctuates from $250 \mathrm{~mm}$ in arid regions, to $1000 \mathrm{~mm}$ in the highlands. Steppes and semi-desert formations are currently developed in several areas of the Armenian territory. In the northeast and the southeast part of Armenia, oak and beech mixed forests are well developed (fig. 1).

The site of Gegharot $\left(40^{\circ} 42.337^{\prime} \mathrm{N}\right.$; $\left.44^{\circ} 13.516^{\prime} \mathrm{W}\right)$ is set on a rocky hillside (2155 $\mathrm{m}$ above sea level) of the Pambak range, on the northeastern edge of the Tsaghkahovit Plain (Aragatsotn Province). The geological substrate of the area consists of a Lower Cretaceous granite intrusion. It composes Gegharot's fortress hill. The western slope of Gegharot fortress is almost completely eroded (Smith et al., 2009). The soils of the study site are underlain by decarbonated mountain-chernozems with carbonates in deep slices (Hovsepyan, 2010).

The Tsaghkahovit Plain is currently under active cultivation by irrigation agriculture, while the slopes of Aragats are largely devoted to pasture (Smith et al., 2009). The study site is set in a mountainous environment totally devoid of trees (fig. 2), except in a few small areas where afforestations of conifers were planted sometime after 1950. Local vegetation belongs to the bioclimatic domain of altitude steppes and subalpine meadows. The mean temperature in January is between -8 and $-10^{\circ} \mathrm{C}$, in April 0 and $2^{\circ} \mathrm{C}$, in July 14 and $16^{\circ} \mathrm{C}$ and in October 6 and $8^{\circ} \mathrm{C}$. Annual precipitation is about $650 \mathrm{~mm}$ (Badalyan and Avetisyan, 2007).

The ongoing excavations at Gegharot have been conducted under the auspices of the joint Armenian-American Project for the Archaeology and Geography of Ancient Transcaucasian Societies (Project ArAGATS). The Early Bronze Age (EBA) settlement at Gegharot consisted 
of a small village which appears to have been established on the citadel and upper terrace during the last centuries of the $4^{\text {th }}$ millennium B.C. and then expanded during the early $3^{\text {rd }}$ millennium to include residential and mortuary complexes on the lower western slope. During the Late Bronze Age occupation (LBA), a fortress hill covered an area of 3.43 ha (Smith et $a l ., 2009)$ and consisted of a variety of built environments including work rooms, storage facilities and ritual shrines that appear to have practiced techniques of divination (Smith and Leon, 2014).

\section{Material and methods}

\subsection{Samples locations from the Gegharot excavations}

The excavations at Gegharot have produced a large quantity of well-preserved charcoals. Samples examined in this study came from operations T18 (excavated in 2006) and T21 (excavated in 2008). These operations were located on the western edge of the citadel (fig. 3). Investigations in $\mathrm{T} 18\left(50 \mathrm{~m}^{2}\right)$ and the adjacent operation, $\mathrm{T} 17$, uncovered a two room complex constructed on bedrock which contained a large quantity of charcoal that likely resulted from an accidental fire event (Badalyan et al., 2008). The analyzed samples included in this study came from a domestic clay floor (T18 $\Delta 13)$ and a domestic storage pit (T18 $\Delta 32)$. The archaeological interpretation of the charcoals extracted from the floor suggests that they derived from structural timbers or roofing materials that collapsed during the fire. The sample T18 $\Delta 32$ is from the Early Bronze I period (defined by Elar-Aragats group ceramics) and has been dated by AMS radiocarbon dating to 3101-2907 cal. BC. The second sample T18 $\Delta 13$ has been related to the Early Bronze II phase (defined by Karnut-Shengavit group ceramics) dated by AMS radiocarbon determinations to between 2899 and 2668 cal. yrs BC and 2861 and 2490 cal. BC (Badalyan et al., 2008).

Samples from T18 $\Delta 16$ and T21 were recovered from the Late Bronze Age (LBA) occupation of the site. T21 $\Delta 6$ has been radiocarbon dated to the Late Bronze Age (1370-1053 cal. yrs BC) with ceramic evidence suggesting a primary occupation during the Late Bronze II phase (Badalyan et al., in press). Charcoals were found on the floor of the West Citadel shrine which was built atop bedrock (T21 $\Delta 6$ ) while two other samples came from storage pits set in the shrine floor (T21 $\Delta 37 \& 54)$. Like the EBA samples from T18 (T18 $\Delta 13)$, the charcoals recovered from the LBA floor (T21 $\Delta 6$ ) are likely the result of roof collapse precipitated by a fire event. The last LBA sample, from T18 $\Delta 16$, is from a storage pit (Badalyan et al., 2008).

\subsection{Methods}


Charcoal identification was based on examination of wood anatomy across a transverse section and two longitudinal ones (radial and tangential) under a reflected light microscope (magnification 200 to 500x). The references used in identifying charcoals were Schweingruber (1990), Akkemik and Yaman (2012), and the collection of the Archeosciences Laboratory of the University of Rennes 1 (CReAAH). Most of the charcoal fragments could be identified at the genus level depending on the sameness of their anatomy. For paleovegetation reconstruction, a sufficient number of charcoals is required. Generally, occupation floors are good indicators, because they have a slow rate of deposition and arise from many possible origins (Chabal et al., 1999). Regardless of the state of preservation, the minimal number of identified charcoals depends on the saturation curve of taxa occurrence within one sample established during the charcoal study. The saturation point is obtained with the levelling off of the curve and seems to ascertain the taxa present in the sample (Chabal, 1997; Ocarrol and Mitchell, 2012). The saturation points has been reached for the samples T18 $\Delta 13$ (no. charcoals $=150$; fig. 4 ), T18 $\Delta 16$ (no. charcoals $=186)$, T21 $\Delta 6$ (no. charcoals $=140$ ) and T21 $\Delta 37$ (no. charcoals $=150$ ). Despite the 250 charcoals analysed in T18 $\Delta 32$, the levelling off of the line was not observed. All the charcoals sampled from T21 $\Delta 54$ (no. charcoals $=100$ ) were studied, that number was not enough to obtain the saturation point.

A systematic examination of the ligneous structure on transverse section was conducted using a stereomicroscope (magnification 9 to $90 \mathrm{x}$ ) to obtain dendrological information. This approach yields valuable ecological and climatic data but it also enables us to identify which part of the tree was transformed into charcoal notably by the evaluation of the growth ring curvature (Marguerie and Hunot, 2007) and the estimation of the wood diameter thanks to trigonometric methods, based on the angle between rays forming an isosceles triangle, established by Dufraisse (2002), completed by Paradis-Grenouillet et al. (2013). When pith and bark appeared together in a sample, it was possible to measure the complete radius and the wood section from which it came. For the many charcoals that do not include preserved bark, the minimal wood diameter was estimated. The predominance of charcoals with weakly curved rings suggests the use of large caliber wood such as trunks or large branches. On the other hand, abundant charcoals with strongly curved rings in one sample indicate the use of small caliber wood or branches. By combining the criteria of ring-curvature and the presence of bark, pith or reaction wood, it was possible to define the type of branches. The presence of tyloses, a close-packed cellular structure blocking the vessel cavity, was also rated on oak, ash and willow charcoals where systematic observation indicated that the fragments were derived from heartwood (Marguerie and Hunot, 2007) (fig. 5B). 
The observation of the last ring before the bark in the ring porous wood and semi-ring porous wood indicates the season of death. In temperate climate area, one ring of ring porous or semi-ring porous wood is characterized by the establishment of the earlywood (from April to June) followed by latewood (from June to September) (Schweingruber, 1990). With altitude, the vegetation period decreases. At Gegharot for instance, latewood establishment encompasses the months of May to October. A ligneous plant needs an average daily temperature up to $+5^{\circ} \mathrm{C}$ to grow (Rameau et al., 1993). Figure 6 shows the transverse section of Betula (fig. 6A-D) and Salix (fig. 6E-F) from the Gegharot excavations that have the particularity to be clearly semi-ring porous. So, the distinction of a complete (fig. 6C-F) or incomplete (fig. 6A-B) ring before the bark, is in this case possible.

When a charcoal fragment was large enough, with a transverse section having a readable record, and regular width rings, we systematically measured the average growth ring width. It was also possible to produce growth curves for large charcoals that contained dozens of rings. In practice, these curves were built by direct measurement under a stereomicroscope or with a tree-ring digital positioning table (accuracy: $0.01 \mathrm{~mm}$ ) by examining the ligneous structure of charcoals on transverse sections. These two methods of measuring gave very similar results. One raw curve by charcoal was thus obtained along one or several rays.

To remove age trend or other long-term variations, and to allow a better comparison, ring width series were standardized. The standardization of ring width highlights yearly changes in tree growth and helps to underline the common signal of trees from the same population. We applied a cubic spline function (Cook and Peters, 1981) to each series. Indexed series were obtained by dividing measurement values by expected values. Crossdating was tested using COFECHA (Holmes, 1983; Grissino-Mayer, 2001).

The average growth ring width could also provide information on the growth conditions of the trees. In one sample of charcoals, this parameter was calculated for each charcoal with readable and measurable rings (fig. 5A). This allowed for the construction of an intra-site frequency distribution of the charcoal ring-widths by classes of $0.25 \mathrm{~mm}$ for each taxon and for each sample of charcoal. A unimodal distribution was interpreted as indicative of a homogeneous stand or a single tree. A multimodal distribution described a heterogeneous community of trees or several populations.

Dendrochronological analysis of the largest charred wood fragments from the Bronze and Iron Age sites under examination by Project ArAGATS is currently underway at the Malcolm and Carolyn Wiener Laboratory for Aegean and Near Eastern Dendrochronology at Cornell 
University, under the supervision of Dr. Sturt Manning. Together with a Bayesian analysis of the large AMS radiocarbon corpus derived from ongoing research in the Tsaghkahovit Plain, this new chronological model promises to provide greater resolution to the extant phases of the Bronze and Iron Ages in the Tsaghkahovit Plain.

The dendro-anthracology methods adopted in this study can also provide information on the wood state before the carbonization. For instance, wood-boring insect or woodworm degradation can be observed in some charcoals. The presence of many bore-holes indicates a biological attack on dead, sick, or senescent wood. Furthermore, the dendro-anthracology methods supplied information about the carbonization itself (Marguerie and Hunot, 2007). The frequency of radial cracks depends on the wood anatomy but also on combustion conditions, among other factors (Théry-Parisot and Henry, 2012).

\section{Results}

The occupation floors under examination contained charcoals belonging to a set of four to six taxa while the pit contexts included two to six taxa. Altogether, from the floors and pits, 976 charcoals and nine taxa were identified. Across the floors and pits of the Early and Late Bronze Age, all taxonomic assemblages showed the clear dominance of birch (Betula) (except in T18 $\Delta 16$ ) (fig. 7).

\subsection{Early Bronze Age charcoal analysis}

During the EBA, birch (almost $70 \%$ in T18 $\Delta 13$ and $\Delta 32$ ) was found with ash (Fraxinus) $(16.7 \%$ in T18 $\Delta 13)$ and willow (Salix) $(27.6 \%$ in T18 $\Delta 32)$. In the T18 $\Delta 13$ sample, less than two percent of deciduous oak (T18 $\Delta 13$ ), wild fruit trees (Pomoïdeae), maple tree (Acer) and spindle tree (Euonymus) (T18 $\Delta 32)$ were identified (fig. 7).

In the T18 $\Delta 13$ and $\Delta 32$ samples, the estimated diameters did not exceed $12 \mathrm{~cm} .87 \%$ of the measured and estimated diameters were less than $5 \mathrm{~cm}$ (fig. 8). Furthermore, nine charcoals which still had both pith and bark corresponded to one to ten year old twigs or young branches. The increase in birch ring-widths was from 0.75 to more than $3.5 \mathrm{~mm}$ with an average of $1.86 \mathrm{~mm}( \pm 0.8 \mathrm{~mm}$; no. charcoals $=94$; no. rings $=411$; fig. 9$), 90 \%$ of the charcoal samples came from strongly curved tree-rings (fig. 8). Striations of the reaction woods were observed in some samples of birch and willow, particularly in a charcoal from T18 $\Delta 13$ (fig. 10). Therefore, most of the charcoals of the T18 $\Delta 13$ and $\Delta 32$ samples seemed to be the result of the carbonization of branches. Some observations of the last ring before the 
bark on birch and willow revealed a tree death mostly from October to May (90\%; no. charcoals $=20$; fig. $6 \mathrm{C}-\mathrm{D})$.

\subsection{Late Bronze Age charcoal analysis}

The four LBA samples studied showed varied results. Charcoals from pit T18 $\Delta 16$, contained a high proportion of pine (Pinus) (75.8\%), and birch (24.2\%), while pit T21 $\Delta 54$ was poor in pine but rich in oak ( $41 \%$ in T21 $\Delta 54)$. According to the 390 charcoals studied from T21, the disappearance of ash trees coincided with the appearance of pine and an increase in wild fruit trees $(16 \%$ in T21 $\Delta 37)$ and oaks $(41 \%)$. Willow was present in two samples (14\% in T21 $\Delta 37 ; 6.4 \%$ in T21 $\Delta 6$ ). One maple charcoal and one elm (Ulmus sp.) were also identified (fig. 7).

From pit T18 $\Delta 16$, the pine tree-ring width of the moderately curved rings was from 0.18 to $1.82 \mathrm{~mm}$ with an average of $0.62 \mathrm{~mm}( \pm 0.30 \mathrm{~mm}$; no. charcoals $=71$; no. rings $=847$; fig. 9$)$. This result suggested small radial growth. Mostly branches or young trunks were recorded, $81 \%$ estimated and measured diameters are less than $5 \mathrm{~cm}$ (fig. 8). Furthermore, ten charcoals which still had both pith and bark came from two to nineteen year old branches. However, two pine charcoals, from pit T18 $\Delta 16$ had a caliber greater than $20 \mathrm{~cm}$ (fig. 8). Some observations of the last ring before the bark on birch revealed a tree death mostly from October to May $(71.4 \%$; no. charcoals $=21)$.

Each T21 sample dating to the LBA, contained at least one charcoal coming from a wood for which the estimated diameter was greater than $20 \mathrm{~cm}$ (fig. 8). The maximum estimated caliber $(50 \mathrm{~cm})$ corresponded to one oak charcoal from the floor in T21 $\Delta 6$. As in the previous occupation of the EBA, many small diameters were recorded. From $67 \%$ (T21 $\Delta 37)$ to $80 \%$ (T21 $\Delta 54$ ) of the charcoals had less than $5 \mathrm{~cm}$ estimated and measured diameters. The typical features of the reaction wood had also been observed in willow and birch charcoals, more especially in the T21 $\Delta 6$ sample (fig. 10). The last ring before the bark was always complete among the 119 charcoals observed (fig. 6E-F). The measurements of the birch ring-width seemed to indicate a smaller growth than during the EBA settlement, except in T18 $\Delta 16$ (fig. 9). T21 $\Delta 37$ birch charcoals with moderately curved rings had an average width of $0.90 \mathrm{~mm}$ $( \pm 0.27 \mathrm{~mm}$; no. charcoals $=21$; no. rings $=170)$, while that of the T21 $\Delta 6$ sample was of 1.37 $\mathrm{mm}( \pm 0.46 \mathrm{~mm}$; no. charcoals $=20$; no. rings $=88)$.

Unlike the EBA, the LBA showed more irregular ring widths. The rate of irregular ring widths was $4.3 \%$ in the birch charcoals during the EBA (no. charcoals $=93$ ). This rate was 
9.9\% in the LBA ones (no. charcoals $=233$ ). Furthermore, irregular radial growth was also observed in many pine and oak charcoals (pine: $38.6 \%$, no. charcoals $=153$; oak: $48.8 \%$, no. charcoals $=43$; fig. 11). This irregular growth was characterized by a series of narrow rings (difficult growth period) amongst wider rings (fig. 5B). Charcoals from LBA contexts showed weaker and more irregular growth possibly due to more challenging climatic conditions.

\subsection{Oak tree-ring crossdating}

From the LBA contexts, each tree-ring series was measured on 23 oak charcoals (from one charcoal in T21 $\Delta 6$ with 75 rings; from 22 charcoals in T21 $\Delta 54$ with 20 to 63 rings, total no. rings $=895)$. An observation of the overall growth trends led to the selection of eighteen pieces of oak charcoal from T21 $\Delta 54$ for tree-ring analysis. The number of tree-rings on the analysed charcoal pieces varied from 26 to 75 . We tried to crossdate them together, despite the fact that the number of rings was lower than the number habitually used for such an approach. Because of the strong common signal between samples, crossdating should be possible.

Nine oak series were crossdated together. The relative position of each sample is shown in figures $12 \mathrm{~A}$ and 12B. Due to the curvature of the rings observed in crossdated charcoals (stars in figure 12B) and decreasing ring width (fig. 12A), it seems that charcoals came from near the pith of the trees. The proposed crossdating suggests that these oaks could be from the same cohort. Potentially, they could have begun their growth at the same time, and belong to a same stand.

Although the number of tree-rings is relatively low (no: 72), the common signal of the trees is acceptable since it reached the generally accepted level of a significance of 0.85 (EPS: 0.8552). Among the statistical characteristics of the series, the autocorrelation is good (order 1: 0,109 ; order 2: 0,05 ) and the mean sensitivity is 0,163 . The average of 25 year's segment correlation (lagged 12 years) is relatively high ( $r$ Pearson: 0.44). An indexed mean series, covering a period of 72 years was calculated (fig. 12C).

\subsection{Pine tree-ring crossdating}

Three pieces of pine containing 36 (from T21 $\Delta 54$ ), 52 and 65 tree-rings (from T18 $\Delta 16$ ) were also analysed. As for the oak series, we use COFECHA to crossdate the samples but no satisfactory results were obtained.

\subsection{Wood state before the carbonization}


Finally, $40 \%$ of charcoals from the floors of both occupations (T18 $\Delta 13$; T21 $\Delta 6)$ had high rates of insect degradation. In contrast, less than 5\% of the charcoals coming from the storage domestic pits had such bore-holes (fig. 13). No charcoal from any sample showed radial cracks or was vitrified.

\section{Discussion}

The Gegharot anthracological results reflect wood collection practices, or more generally, the human management of plant resources in the vicinity of the archaeological site. Based on the ecological characteristics of each attested species, we were also able to detect information about some paleo-environmental conditions.

\subsection{Paleo-environmental approach}

According to the results of this study, at least two EBA biotopes were identified. The clearest one was an open woodland with birch, Pomoïdeae such as Sorbus and Acer. Today in the Lesser Caucasus, above 1800 / 2000 m a.s.l., a subalpine vegetation composed of open woodlands, krummholz, and dwarf shrub communities in combination with grasslands and tall-herb communities predominates (Zazanashvili, 2000). The taxa associated with the EBA occupation at Gegharot are typical of the composition of the birch-krummholz forests (Betula litwinowii, Sorbus aucuparia, Acer trautvetteri, Populus tremula and Salix caprea) which occur today mostly in areas with high precipitation in the uppermost foothills (western Lesser Caucasus; above 2000 m a.s.1.; Zazanashvili, 2000). Based on the species recorded, the large quantities of the reaction wood in birch Gegharot charcoals and the predominantly small caliber wood (below $5 \mathrm{~cm}$ ) in both occupations, a great part of the ligneous resources could have been derived from birch-krummholz forests. On the Tslaka Plateau (Georgia), the current vegetation is classified as mountain steppes devoid of any forest vegetation, the rainfall and temperature averages are close to those prevailing at Gegharot. The botanical data obtained for the Bronze Age landscape on the Tsalka Plateau suggested an altitudinal zonation of the vegetation. A subalpine birch krummholz could have thrived at $2100 \mathrm{~m}$ a.s.l., then below this elevation to approximately $1800 \mathrm{~m}$ a.s.l. a coniferous plant community could have existed (Connor and Sagona, 2007).

Secondarily, at Gegharot, the presence of deciduous oak can refer to an open forest biotope; the oak (Quercus macranthera) is currently present in open woodlands formations with maple (Acer trautvetteri), birch and ash-birch elfin woods (Betula litwinowii / raddeana, Sorbus 
caucasigena) in the lower subalpine belt (1900 - $2200 \mathrm{~m}$ a.s.l.; Zazanashvili et al., 1995). A wet zone can also be attested, where willows and some ash-trees grew (fig. 14B).

During the LBA at Gegharot, the vegetation appears to have been different. Ash trees disappeared and some elm trees were recorded but the main phenomenon was the clear rise of oak, pine and wild fruit trees. The available plant resources of the LBA seemed to have been changed (fig. 14A). The establishment of a colder and drier climate could be the cause of the disappearance of the ash trees and the appearance of oak pine forests. Currently pine and oak forests (Quercus macranthera, Pinus kochiana, Acer trautvetteri) grow in the drier areas of the eastern part of the South Caucasus near the lower subalpine foothills (Zazanashvili, 2000; Zazanashvili et al., 1995; 1900 - 2200 m a.s.l). Moreover, the birch average ring width showed a reduced radial growth during the LBA and the series of pine and oak rings at that time recorded a difficult growth period. Unlike our results, pollen analysis from the Zarishat mire (Armenia, $2116 \mathrm{~m}$ a.s.1.) and from the Javakheti Plateau (Georgia, $2073 \mathrm{~m}$ a.s.l.) recorded a decline of the pine forest during the LBA (Joannin et al., 2014; Messager et al., 2013). In the Javakheti Plateau, pollen analysis showed nevertheless an expansion of Picea which could be linked to the colder climatic conditions of 3200 cal. BP (Messager et al., 2013). Around $4000 \mathrm{cal}$. BP at the Lake Imeria on the Tsalka Plateau (Georgia, $\pm 1600 \mathrm{~m}$ a.s.1.), pollen analysis recorded a switch from oak to pine and fir which could also be the result of a colder climate (Connor and Sagona, 2007). At Van Lake (Turkey, 1648 m a.s.1.), between 4000 and $2100 \mathrm{cal}$. BP, the higher charcoal values and a rise in the $\mathrm{Mg} / \mathrm{Ca}$ ratio inside the pollen sequence indicated an opening of the woodlands, interpreted as increasing aridity (Wick et al., 2003). Furthermore, Roberts et al. (2011) characterized the Late Bronze Age as the beginning of the Dry late Holocene ( $\delta^{18} \mathrm{O}$ analyses$)$, from 1200 to $850 \mathrm{BC}$.

Human impacts on the environment could be also a cause of vegetation change at Gegharot during the LBA. The rise of wild fruit trees in particular could be a consequence of the clearing and degradation of the environment. During the LBA, the increasing number of settlements in the Tsaghkahovit Plain and the significant demographic expansion (Badalyan et al., 2010 b) could have caused significant deforestation as communities cleared more terrain of forest cover and consumed more wood. The wood and charcoals assemblages from the Middle Bronze Age to the Late Iron Age at Kaman-Kalehöyük in central Anatolia (Turkey; Wright et al., 2015), indicate the increase of the exploitation of old broadleaf woodland during the Middle Bronze Age (MBA) and the LBA. The decline of the taxa exploited during the LBA is interpreted as a well-established woodland of earlier periods under significant anthropogenic pressure. 


\subsection{Woodland exploitation}

During the EBA, most of the branches or twigs derived from T18 were collected from October to May, the other part from May to October. According to the interpretation of faunal remains from the site at least a part of Gegharot's EBA population led a sedentary life (Monahan, 2007; Badalyan et al., 2010b). During the LBA occupation at T21, seasonal activities may have occurred according to the last tree-ring observed (only complete last ring before the bark).

During both occupations at Gegharot, people mainly used twigs, branches or young trunks undoubtedly harvested from stands proximate to the settlement. This preponderance of the small diameters can be interpreted as a selection choice and/or determined by the woodland availabilities (Krummholz formation or human pressure on the woodland). The observation of the current vegetation at the Taurus foothill zone (Turkey; Asouti and Kabukcu, 2014), shows that small-sized, stunted trees and shrubs occur in very open formations and as old-growth coppices near village. The exploitation of the willow during the EBA joined by the elm during the LBA at Gegharot (fig. 14), can be interpreted as an anthropogenic disturbance at the expense of the riparian woodland which can be lead by the need in agricultural or gazing land like at Kaman-Kalehöyük during the LBA (Wright et al., 2015; $1070 \mathrm{~m}$ a.s.1). The high diameters (pine, birch, etc.) estimated during the LBA occupation at Gegharot may correspond to a modification in human choices caused by new demands upon timber which led to the expansion of the catchment area.

The high rate of birch charcoals with bore-holes in T18 $\Delta 13$ and T21 $\Delta 6$ may indicate that the wood was in place for a long time, exposed to insect attacks as would be the case in a roof structure. This could support the archaeological interpretation that the charcoals predominately derived from a fire event which caused the roof to collapse. Changes in wood calibre between the floors of T21 and T18 may be linked to different approaches roofing with (1) in T18 a roof built with branches and (2) in T21 a roof with timbers from larger wood calibers and branches. A behavioral ecology modeling was built with the archaeological and ecological data from the site of Gordion, in Central Anatolia (modern Turkey; Marson, 2009) with an occupation since the EBA through the Medieval Period. This model suggests that the wood for fuel came from the local availability. While, more distant woods were selected for construction. In contrast, the taxa list and the high proportion of small caliber recorded in the T18 $\Delta 13$ and T21 $\Delta 6$ interpreted as roof from Gegharot seem to reflect the resources available in the local woodlands. Nevertheless the high diameters estimated on oak, pine and birch in 
T21 $\Delta 6$ can be linked to a specific choice leading to the exploitation of more distant and/or older woodland for construction. These woods are easy to process and are suitable for construction because of their mechanical resistance (upper than $120 \mathrm{~N} / \mathrm{mm}^{2}$; Sell and Kropf, 1990). Birch and oak are hardwoods able to bend and are thus well-suited for timber (notably as roof beam; Sell and Kropf, 1990; Chabal et al., 1999). Notably, oak, pine, willow/poplar, elm and ash have also been recorded from woods remains dated to the Late Chalcolithic period (3350-3000 BC), at Arslantepe where they are interpreted as roof constructions (Malatya, Turkey; Salory et al., 2008).

Many seeds were recovered from the EBA pit $(\Delta 32)$ and domestic floor $(\Delta 13)$ of T18 (Hovsepyan, 2008, 2010). Charcoals samples can thus be linked to stages in grain processing. The charcoals extracted from pits (T21 \& T18, except T18 $\Delta 16)$ according to their taxonomic diversities may be waste resulting from human activities (domestic, craft activities, agriculture, forestry, building, etc.).

\section{Conclusion}

The anthracological data from Gegharot have allowed us to study two occupation periods. Unlike the deforested steppe and subalpine meadow vegetation that defines the ground cover around Gegharot today (fig. 2), different vegetation biotopes were identified during the Bronze Age. During the EBA, wood supplies seem to have been collected at the shrub layer (branches of a diameter less than $12 \mathrm{~cm}$ ), probably near the settlement, in an open woodland with birch trees. Wood collection during the LBA centered on a pine and oak forest surrounded by open areas and wetlands.

The establishment of a colder and drier climate could be the cause of the disappearance of the ash trees and the appearance of oak pine forests and the decrease of the average birch ringwidth during the second occupation. Similarly, the average weak growth of a long series of charcoal rings may be related to restrictive climatic conditions.

This study supports the conclusion that climatic variation resulted in significant changes in ground cover during the Bronze Age (recorded through vegetation establishment and growth of trees) and would likely also have required some response in social practices. Human impacts (clearing and degradation) on the environment should nevertheless not be ruled out (e.g. the rise of wild fruit tree during the LBA could be one proof of human intervention). The distinction between climatic variations and anthropogenic impacts on the environment is difficult to tease apart. Nevertheless, during the Bronze Ages both clearly impacted the landscape. Observation of the last ring before the bark in many carbonized branches may 
reveal a pattern of EBA wood collection was not seasonal, while the LBA activities in T21 appear to have occurred only seasonally or at least from October to May.

This study was the first systematic and large-scale application of charcoal analysis examining the Bronze Age in Armenia. Additional analyses of charcoals from archaeological settlements at different altitudes are required in order to test the hypothesis that a colder and drier climate prevailed during the LBA.

The oak tree-ring crossdating study provides an indexed mean series, covering a period of 72 years within the LBA. The forthcoming radiocarbon/dendrochronological model in development at Cornell University, incorporating the largest samples of charred wood from Gegharot, will aid in building a tree-ring series for the Bronze and Iron Age South Caucasus. More generally, additional charcoal samples from archaeological investigations would be desirable in order to study not only Holocene climate conditions but also human-environment interactions at various periods in the South Caucasus. A study of the Achaemenid period is already in progress based on remains from the site of Erebuni, Yerevan. For the Neolithic period, further charcoals analyses in the Ararat Valley, notably at Akhnashen are about to begin. Also, it would be useful to start additional pollen analyses in other parts of Armenia in order to compare with anthracological results and to get a better understanding of both human choices and vegetational evolution in the study area.

\section{Acknowledgments:}

This research was conducted in the scope of the "Humans and Environments in Mountainous Habitats, the case of Armenia” (HEMHA) International Associated Laboratory (LIA). We are thanking Roman Hovsepyan for his valuable help in the knowledge of the current Armenian vegetation and Isabelle Théry Parisot and her student, Guillaume Nannini for their preliminary work on the samples of Gegharot. We are thanking also Anna Azizyan for her decisive help as a Amenian-French translator. Finally, Loic Joanny is acknowledged for SEM images performed at CMEBA (ScanMAT, University of Rennes 1) which received a financial support from the European Union (CPER-FEDER 2007-2014). Fieldwork at the site of Gegharot which recovered the analysed samples was supported by grants from the National Science Foundation, USA and the University of Chicago Department of Anthropology's Lichtstern Fund.

\section{References}


Akkemik, Ü., Yaman, B., 2012. Wood Anatomy of Eastern Mediterranean Species, Kessel Publishing House, Germany.

Asouti, E., Kabukcu, C., 2014. Holocene semi-arid oak woodlands in the Irano-Anatolian region of Southwest Asia: natural or anthropogenic? Quaternary Science Reviews 90, 158182.

Badalyan, R., Avetisyan, P. S., 2007. Bronze and Early Iron Age Archaeological Sites in Armenia. I: Mt. Aragats and its Surrounding Region. British Archaeological Reports International Series 1967, Archeopress, Oxford, England.

Badalyan, R., Lombard, P., Avetisyan, P., Chataigner, C., Chabot, J., Vila, E., Hovsepyan, R., Willcox, G., Pessin, H., 2007. New data on the late prehistory of the Southern Caucasus. The excavations at Aratashen (Armenia): preliminary report, in Lyonnet, P. (dir.), Les cultures du Caucase (VIe-IIIe millénaires avant notre ère), leurs relations avec le Proche-Orient, CNRS éditions, Editions Recherches sur les Civilisations, Paris, pp. 37-61.

Badalyan, R., Smith, A. T., Lindsay, I., Khatchadourian, L., Avetisyan, P., 2008. Village, Fortress, and Town in Bronze and Iron Age Southern Caucasia: A preliminary report on the 2003-2006 Investigations of Project ArAGATS on the Tsaghkahovit Plain, Republic of Armenia. Archäologische Mitteilungen aus Iran und Turan 40, 45-105.

Badalyan, R., Harutyunyan, A. A., Chataigner, C., Le Mort, F., Chabot, J., Brochier, J. E., Balasescu, A., Radu, V., Hovsepyan, R., 2010 a. The settlement of Aknashen-Khatunarkh, a neolithic site in the Ararat plain (Armenia): excavation results 2004-2009. TÜBA-AR 13, $185-218$.

Badalyan, R., Smith, A.T., Khatchadourian, L., 2010b Project ArAgats: 10 years of Investigations into Bronze and Iron Age sites in the Tsaghkahovit Plain, Republic of Armenia. TÜBA-AR 13, 263-276.

Badalyan, R., Smith, A. T., Lindsay, I., Harutyunyan, A., Greene, A., Marshall, M., Monahan, B., Hovsepyan, R., in press. A Preliminary Report on the 2008, 2010, and 2011 Investigations 
of Project ArAGATS on the Tsaghkahovit Plain, Republic of Armenia. Archäologische Mitteilungen aus Iran und Turan.

Bohn, U., Gollub, G., Hettwer, C., 2000. Karte der natürlichen Vegetation Europas. Bundesamt für Naturschutz Federal Agency for Nature Conservation, Bohn-Bad Godesberg.

Chabal, L., 1997. Forêts et sociétés en Languedoc (Néolithique final, Antiquité tardive), l'anthracologie, méthode et paléoécologie. Documents d'Archéologie Française 63. Maison des Sciences de l'Homme, Paris, France.

Chabal, L., Fabre, L., Terral, J.-F., Théry-Parisot, I., 1999. L'Anthracologie. In: Ferdière I. (Eds.). La botanique. Edition Errance, Paris, France, pp. 43-105.

Connor, S., Sagona, A., 2007. Environment and society in the late prehistory of southern Georgia, Caucasus. In: Lyonnet, B. (Eds.), Les cultures du Caucase (VI $\mathrm{e}^{\mathrm{e}}-\mathrm{III}^{\mathrm{e}}$ millénaires avant notre ère). Leurs relations avec le Proche-Orient, Editions Recherche sur les Civilisations. CNRS Edition, Paris, France, pp. 21-36.

Cook, E.R., Peters, K., 1981. The smoothing spline: a new approach to standardizing forest interior tree-ring width series for dendroclimatic studies. Tree-Ring Bulletin, 41, 45-53.

Dufraisse, A., 2002. Les habitats littoraux néolithiques des lacs de Chalain et Clairvaux (Jura, France) : collecte du bois de feu, gestion de l'espace forestier et impact sur le couvert arboréen entre 3700 et 2500 av. J.-C., analyses anthracologiques. Ph.D. Thesis, University of Franche-Comté, Besançon, France.

Grissino-Mayer, H.D. 2001. Evaluating crossdating accuracy: A manual and tutorial for the computer program COFECHA. Tree-Ring Research, 57 (2), 205-221.

Holmes, R.L. 1983. Computer-assisted quality control in tree-ring dating and measurement. Tree-Ring Bulletin, 43, 69-78.

Hovsepyan, R. A., 2008. Appendix 2: The paleobotanical remains from Early Bronze Age Gegharot. In: Badalyan, R., Smith, A. T., Lindsay, I., Khatchadourian, L., Avetisyan, P., 
2008. Village, Fortress, and Town in Bronze and Iron Age Southern Caucasia: A preliminary report on the 2003-2006 Investigations of Project ArAGATS on the Tsaghkahovit Plain, Republic of Armenia. Archäologische Mitteilungen aus Iran und Turan 40, pp. 97-101.

Hovsepyan, R. A., 2010. New data on agriculture of Aparan-III Early Bronze Age settlement (Armenia). Biological Journal of Armenia 4 (62), 31-37.

Joannin, S., Ali, A., Vincent, O., Peyron, O., Chevaux, S., Nahapetyan, S., Tozalakyan, P., Karakhanyan, A., Chataigner, C., 2014. Vegetation, fire and climate history of the Lesser Caucasus: a new Holocene record from Zarishat mire (Armenia). Journal of Quaternary Science 29 (1), 70-82.

Leroyer, C., Joannin, S., Aoustin, D., Ali, A., Peyron, O., Ollivier, V., Tozalakyan, A., Karakhanyan, A., Jude F., in press. Mid Holocene vegetation reconstruction from Vanevan peat (south-eastern shore of Lake Sevan; Armenia). Quaternary International.

Marguerie, D., Hunot, J.-Y., 2007. Charcoals analysis and dendrology: Data from archaeological sites in western France. Journal of Archaeological Sciences 24, 1417-1433.

Marston, J.M., 2009. Modeling wood acquisition strategies from archaeological charcoal remains. Journal of Archaeological Science 36, 2192-2200.

Messager, E., Belmecheri, S., Von Grafenstein, U., Nomade, S., Ollivier, V., Voinchet, P., Puaud, S., Courtin-Nomade, A., Guillou, H., Mgeladze, A., Dumoulin, J.-P., Mazuy, A., Lordkipanidze, D., 2013. Late Quaternary record of the vegetation and catchment-related changes from Lake Paravani (Javakheti, South Caucasus). Quaternary Science Reviews 77, 125-140.

Monahan, B. H., 2007. Nomadism in the Early Bronze Age Southern Caucasus: The Faunal Perspective. In: Popova, L., Hartley, C., Smith, A. T. (Eds.), Social Orders and Social Landscapes. Proceedings of the 2005 University of Chicago Conference on Eurasian Archaeology. Cambridge Scholars Press, London, England, pp. 379-392.

Moreno-Sanchez, R., Sayadyan, H.Y., 2005. Evaluation of the forest cover in Armenia. International Forestry Review 7 (2), 113-127.

OCarroll, E., Mitchell, F.J. G., 2012. Charcoals sample guiltiness: new methodological approaches towards the quantification and identification of charcoals samples retrieved from 
archaeological sites. In: Badal, E., Carrion, Y., Macias, M., Ntinou M. (Eds), Wood and charcoals. Evidence for human and natural History. Pappels del laboratorio de arqueologia de Valencia, Sagvntvm Extra 13, Valencia, Spain, pp. 275-282.

Paradis-Grenouillet, S., Dufraisse, A., Allée Ph., 2013. Radius of curvature measurements and wood diameter: a comparison of different image analysis techniques. In Damblon, F. (Eds.), 4th International Meeting of Anthracology, Brussels: British Archaeological Report Series, 2486, pp.173-182.

Rameau, J.-C., Mansion, D., Dumé, G., Lecointe, A., Timbal, J., Dupont, P., Keller, R., 1992. Flore forestière française : guide écologique illustré, tome. 2, Montagnes. Institut pour le développement forestier ; Ministère de l'agriculture et de la pêche : Direction de l'espace rural et de la forêt ; Ecole nationale du génie rural des eaux et des forêts, Paris, France.

Roberts, N., Eastwood, W.J., Kuzucuoğlu, C., Fiorentino, G., Caracuta, V., 2011. Climatic, vegetation and cultural change in the eastern Mediterranean during the mid-Holocene environmental transition, The Holocene, 21, 147-162.

Sadori, L., Susanna, F., Balossi Restelli, F., 2008. Collapsed beams and wooden remains from a 3200 BC temple and palace at Arslantepe (Malatya, Turkey). In Fiorentino, G., Magri, D. (Eds.), Charcoals from the past. British Archaeological Reports International Series 1807, pp. 237-250.

Sayadyan, Y.V., 1978. Postglacial times in Armenia and adjacent regions. Studia Geomorphica Carpatho-Balcanica (Krakow) 12, 77-93.

Sayadyan, Y.V., 1983. Chelovek i sreda v poslelednikovoe vremya v basseyne ozero Sevan i opredelnikh oblastyakh (Men and environment in postglacial period in Lake Sevan basin and neighbourhood areas). In: Problems of Quaternary Geology in Armenia. Yerevan, Armenia, pp. 67-73 (in Russian).

Schweingruber, F. H., 1990. Anatomy of European Woods: An Atlas for the Identification of European Trees, Shrubs and Dwarf Schrubs. Haupf publisher, Bern and Stuttgart.

Sell, J., Kropf, F., 1990. Propriétés et caractéristiques des essences de bois, Lignum, Le Mont, Suisse.

Smith, A. T., Badalyan, R. S., Avetisyan, P., 2009. The Archaeology and Geography of Ancient Transcausian societies I: The Foundations of Research and Regional Survey in the Tsaghkahovit Plain, Armenia. Oriental Institute Press 134. The Oriental Institute of the University of Chicago, Chicago, US-IL.

Smith, A. T., Leon, J. F., 2014. Divination and Sovereignty: The Late Bronze Age Shrines at Gegharot, Armenia. American Journal of Archaeology 118 (4), 549-563. 
Takhtajyan, A.L. 1941. Botaniko-geograficheskiy ocherk Armenii (Botanical-geographic overview of Armenia). Trudi Botanicheskogo Instituta Armyanskogo filiala akademii nauk SSSR, Work papers of Institute of Botany of Armenian Academy of Sciences, Branch of USSR Academy of Sciences 2 (in Russian).

Théry-Parisot, I., Henry, A., 2012. Seasoned or green? Radial cracks analysis as a method for identifying the use of green wood as fuel in archaeological charcoal. Journal of Archaeological Science 39, 381-388.

Wick, L., Lemcke, G., Sturn, M., 2003. Evidence of Lateglacial and Holocene climatic change and human impact in eastern Anatolia: high resolution pollen, charcoal, isotopic and geochemical records from the laminated sediments of Lake Van, Turkey. The Holocene 13, 665-675.

Willcox, G., 2002. Evidence for ancient forest cover and deforestation from charcoal analysis of ten archaeological sites on the Euphrates. In: Thiébault S. (Eds.), Charcoal Analysis. Methodological Approaches, Palaeoecological Results and Wood Uses. British Archaeological Reports International Series 1063, pp. 141-145.

Wright, N.J., Fairbairn, A.S., Faith, J.T., Matsumura, K., 2015. Woodland modification in Bronze and Iron Age central Anatolia: An anthracological signature for the Hittite state? Journal of Archaeological Science 55, 219-230.

Zazanashvili, N., 2000. Caucasian krummholz- and open woodlands (C41-C47). In: Bohn, U., Gollub, G., Hettwer, C., Karte der natürlichen Vegetation Europas. Bundesamt für Naturschutz Federal Agency for Nature Conservation, Bohn-Bad Godesberg, pp. 162-165.

Zazanashvili, N., Gagnidze, R., Nakhutsrishvili, G., 1995. Main types of vegetation zonation on the mountains of the Caucasus. Acta Phytogeographica Suecica 85, 7-16.

\section{List of figures:}

Fig. 1. Main natural vegetation groups in Armenia (modified from Bohn et al., 2000). Stars represent the Armenian pollen analyses recording the Bronze Age period: 1. Zarishat mire, 2. Vanevan. $C f$. extend European card (C) histgeo.ac-aix-marseille.fr.

Fig. 2. Current landscape surrounding the site of Gegharot (the archaeological site is situated in the rectangle area). 
Fig. 3. The plan of Gegharot showing the locations of T18 and T21 (ex Badalyan et al., in press).

Fig. 4. Saturation curves for taxa occurrences for each charcoal sample from Gegharot (Armenia).

Fig. 5. Anatomical features on Gegharot charcoals (A) Stem of charred oak with large and narrow rings, T21 $\Delta 54$, transverse section; (B) tyloses in oak heartwood charcoal, T21 $\Delta 54$, transverse section; (C) Scalariform perforation in a vessel of a charred birch, T21 $\Delta 37$, radial section; (D) Ash tree charcoal, transverse section, T18 $\Delta 32$ (observed under a reflected light microscope).

Fig. 6. Tree-rings on Betula and Salix charcoals of Gegharot (A) Semi-ring porous wood in Betula, T18 $\Delta 16$, transverse section; (B) Uncompleted last ring before the bark, earlywood, Betula, T18 $\Delta 16$, transverse section; (C) Semi-ring porous wood in Betula, T18 $\Delta 32$, transverse section; (D) Uncompleted last ring before the bark, earlywood and latewood, Betula, T18 $\Delta 32$, transverse section; (E) Semi-ring porous wood in Salix, T21 $\Delta 37$, transverse section; (F) Complete last ring before the bark, earlywood and latewood, Salix, T21 $\Delta 37$, transverse section (observed under a scanning electron microscope).

Fig. 7. Percentage charcoal diagram of Gegharot (Armenia).

Fig. 8. Minimum estimated and measured diameters (cm) diagrams in T18 and T21, Gegharot (Armenia).

Fig. 9. Ring-widths (mm) of charcoals in T18 and T21, Gegharot (Armenia).

Fig. 10. Percentages of reaction wood observed on Betula and Salix in T18 and T21, Gegharot (Armenia).

Fig. 11. Number of regular and irregular ring width observed in charcoals from T18 and T21, Gegharot (Armenia). 
Fig. 12. Superposition of tree-ring measurements for the nine cross-dated samples from T21 $\Delta 54$ (A), and life period of these charcoals (B). Black stars indicate charcoals with strong curved first rings and red stars indicate moderately curved rings. (C) Indexed tree-ring series for oak.

Fig. 13. Percentages of insect degradations observed on Betula in T18 and T21, Gegharot (Armenia).

Fig. 14. Interpretation of the altitudinal distribution of the past local woodland and its evolution during the EBA (B) and the LBA (A); Location of the transect (C; modified from Smith et al., 2009, plate 21, 24); Keys (D); (C.A.D. L. Quesnel). 


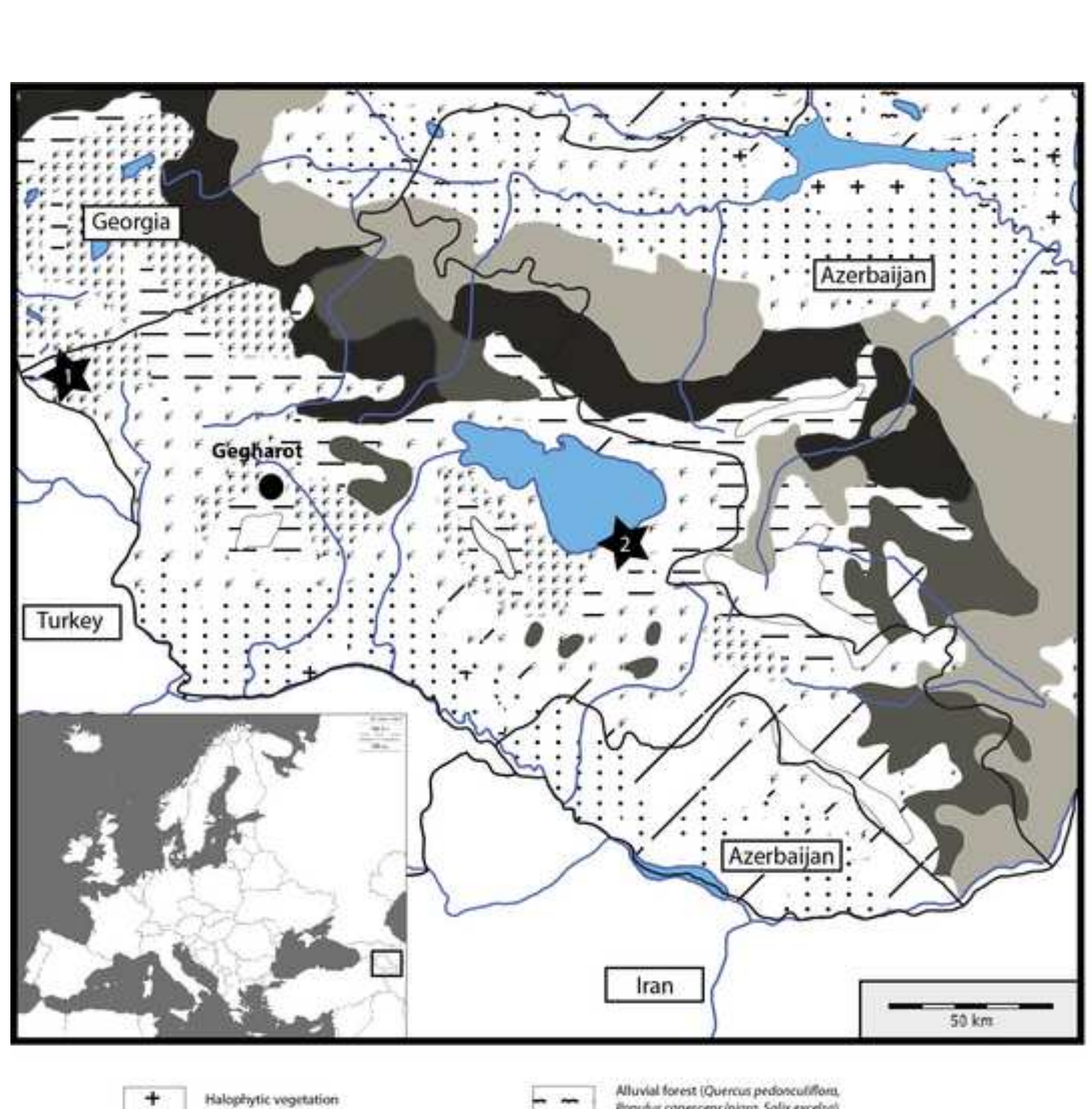

- - Mluvial forest (Quencus pedoscullora. Pepotos conescensinigne Solix everiat?

$1 / 2$ forest deppe vegetation

Overcus iterica-Caphos berulai forest

Atimonane oak forests (Quercis mochanabeal

Fogus orimtaft - Caminus befulur - Queritut berita forests 
Figure 2 color
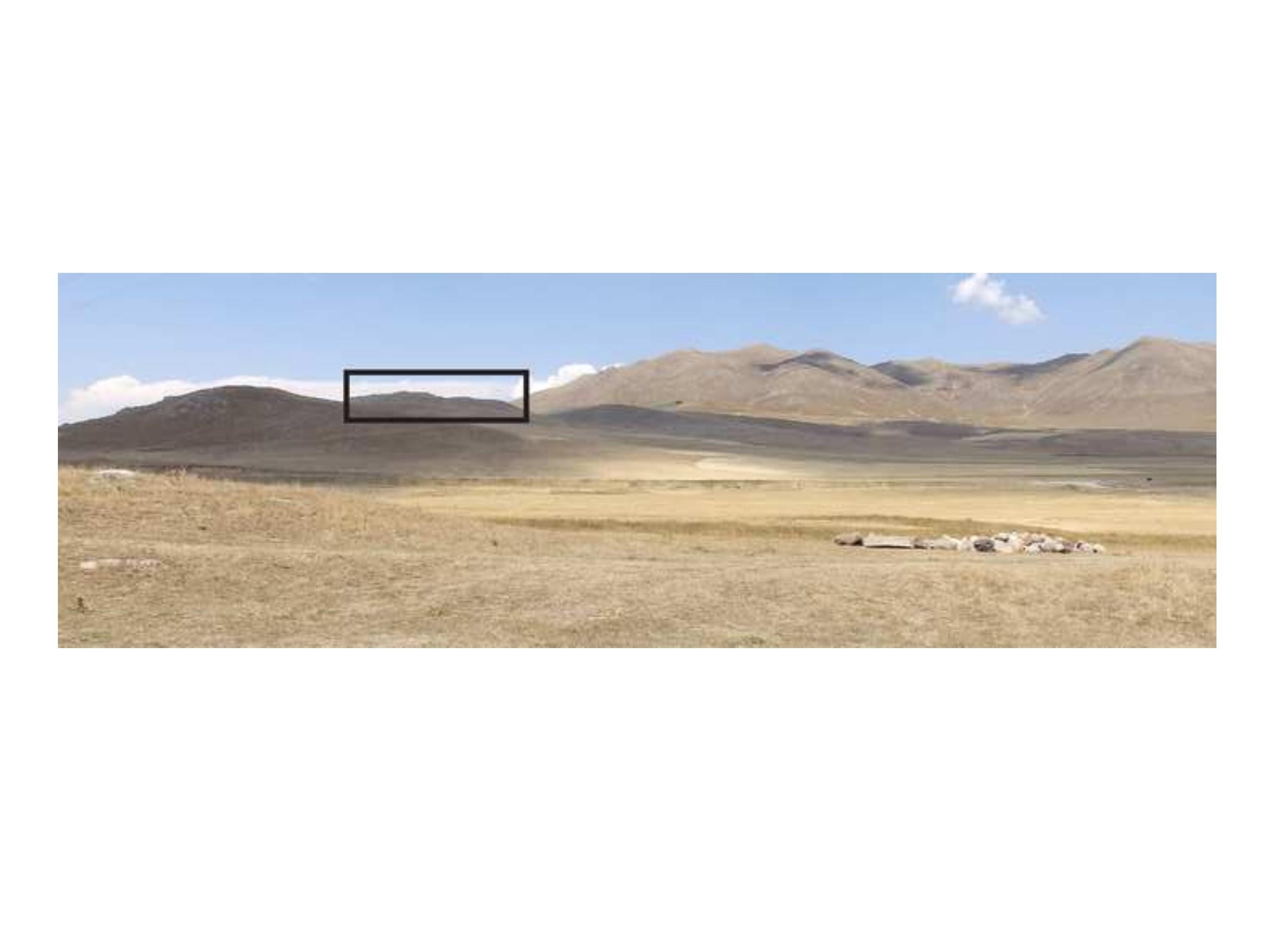
Figure 3 color
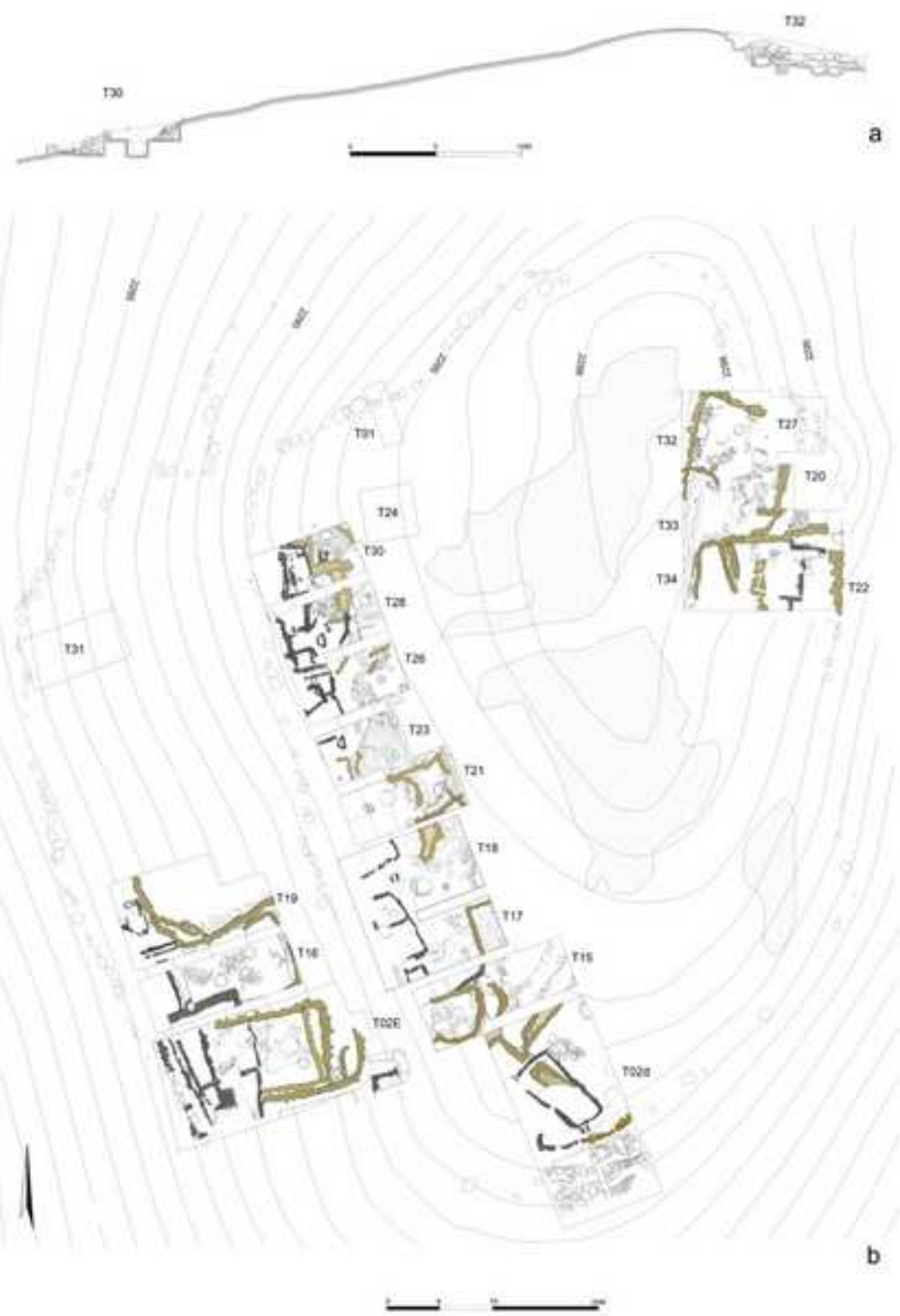

EiII - Earty Bronsa Ace conatructions

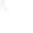

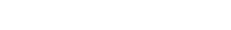



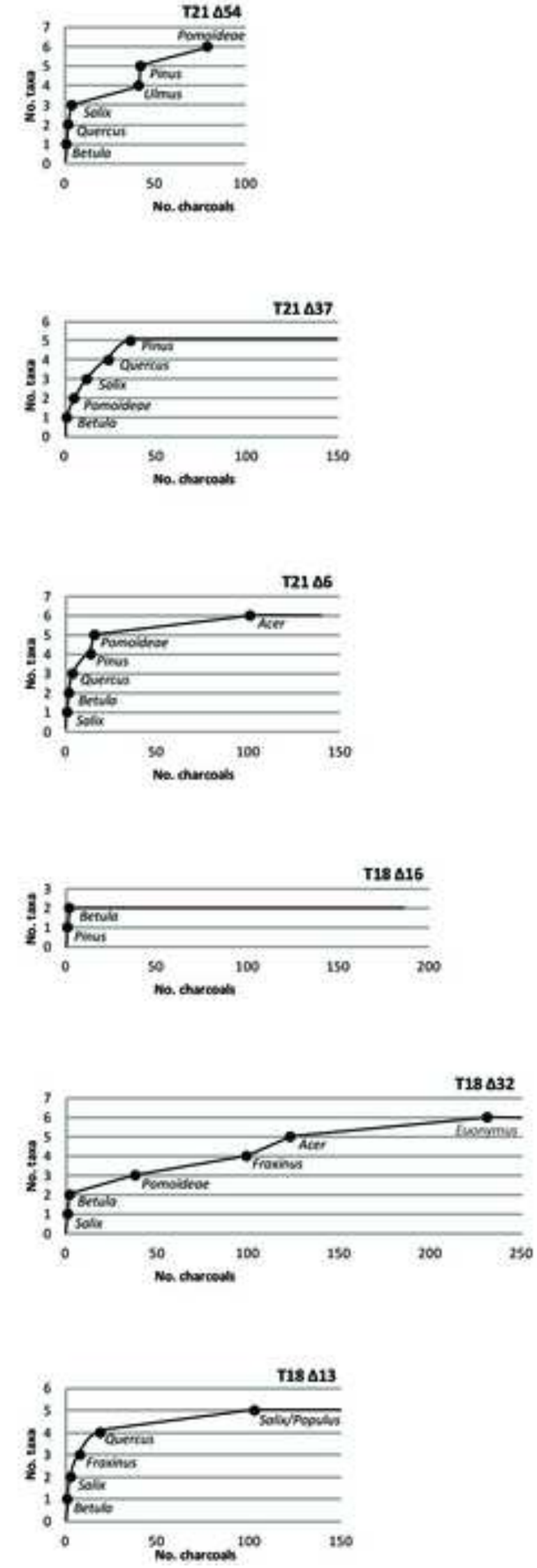

Figure 4 
A

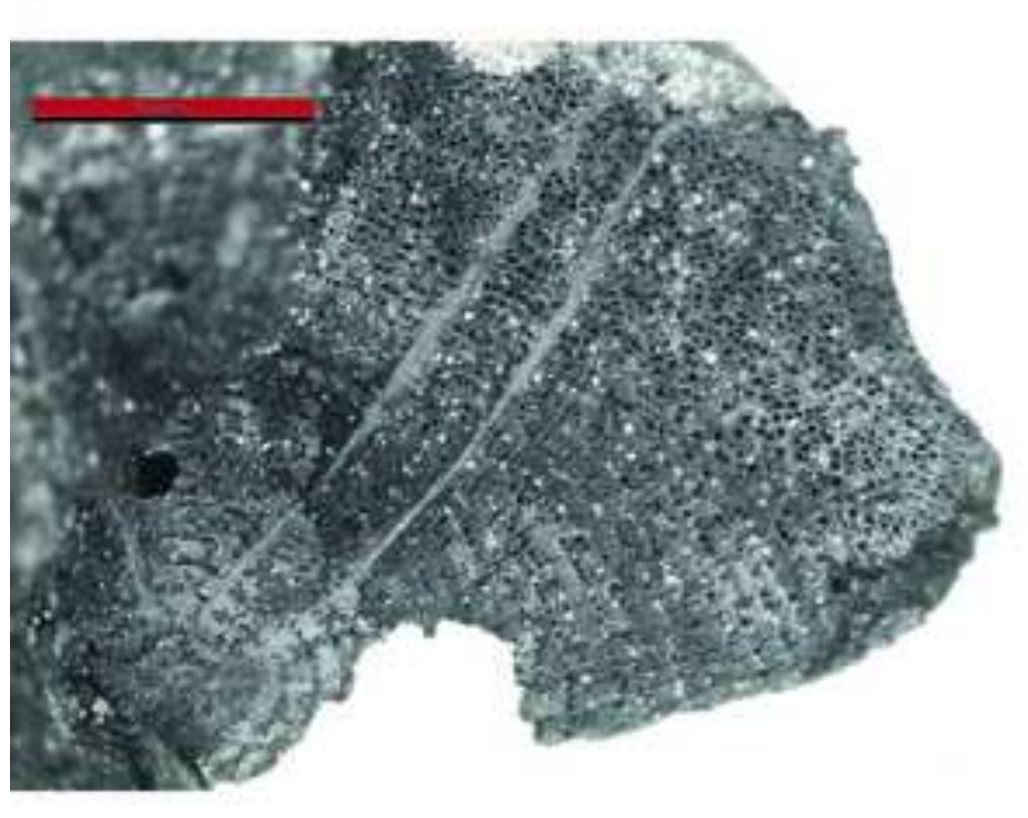

C
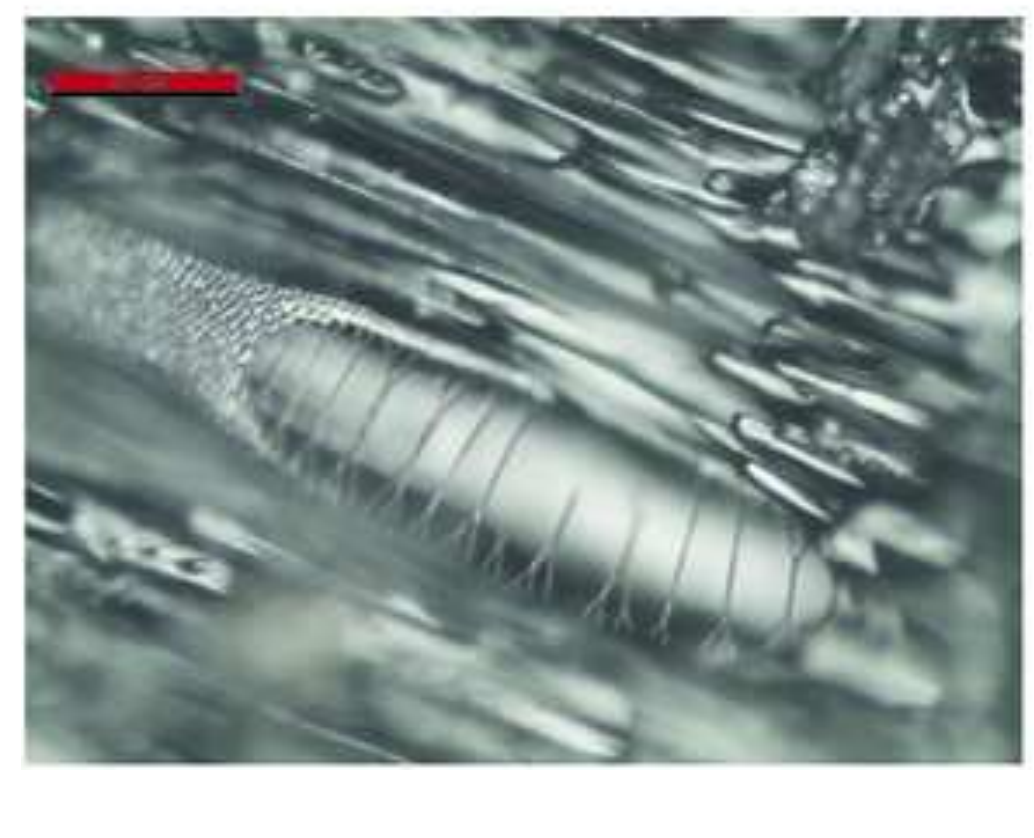

B

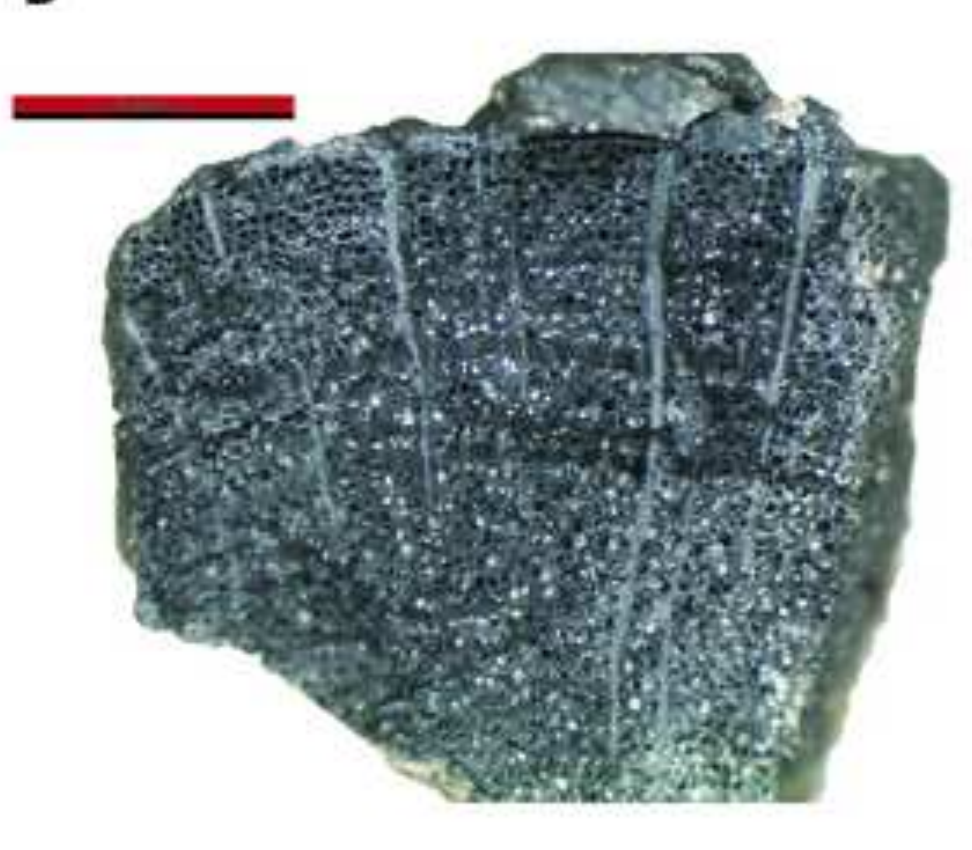

D

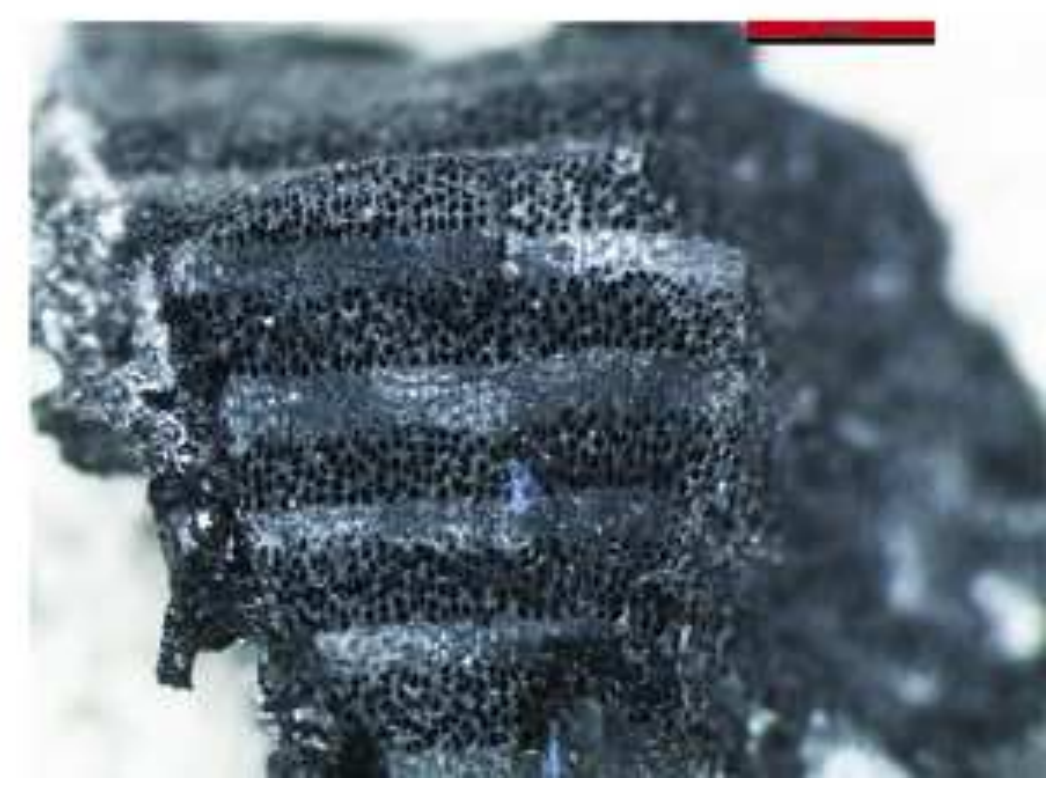

is
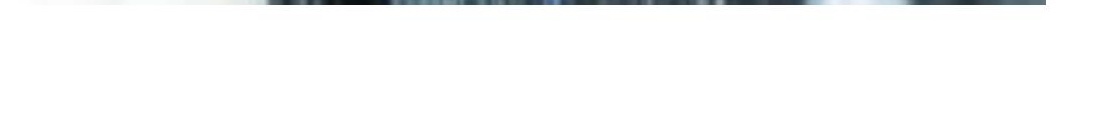
A

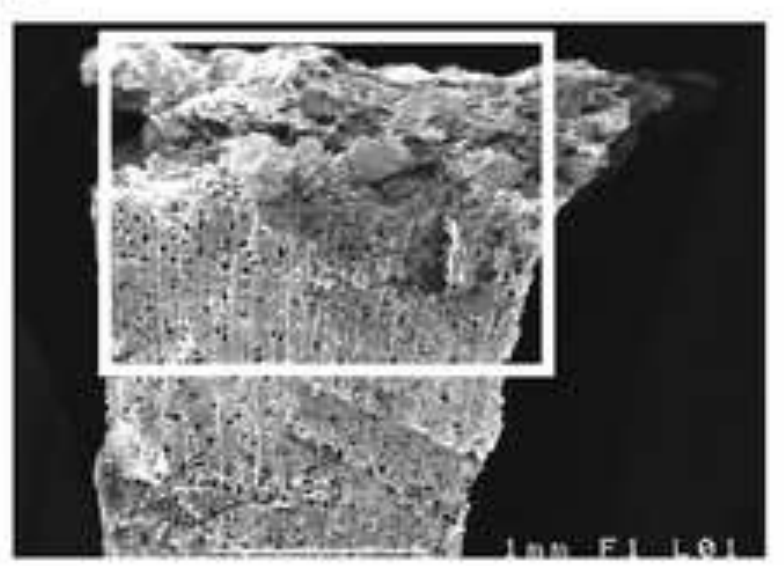

c

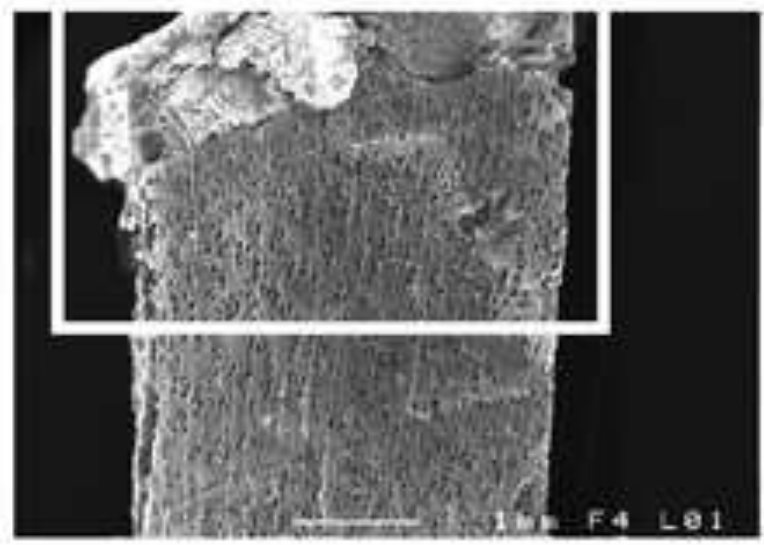

E

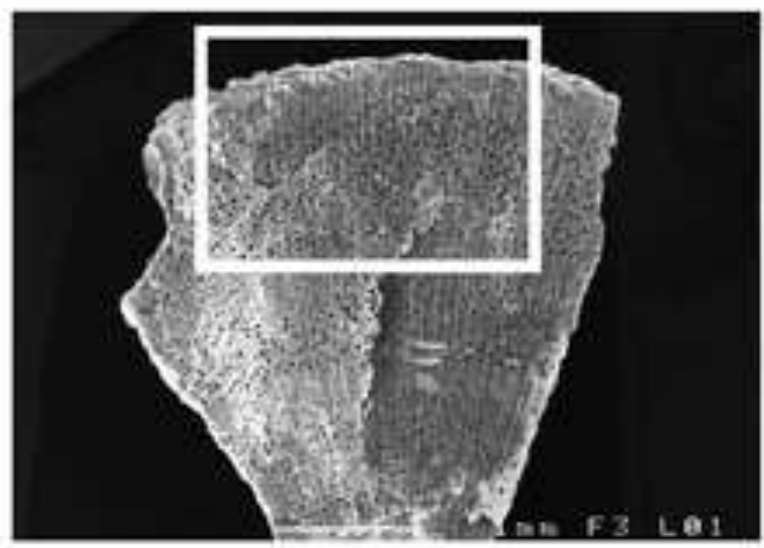

B

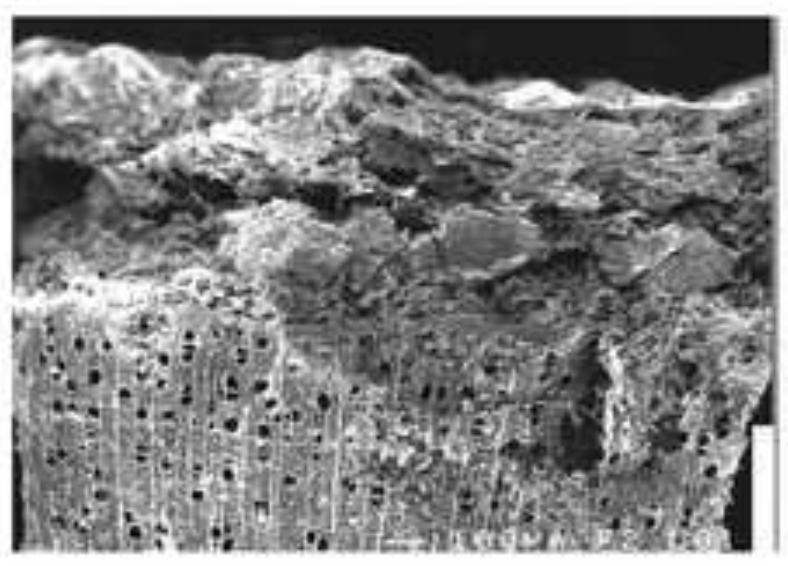

D

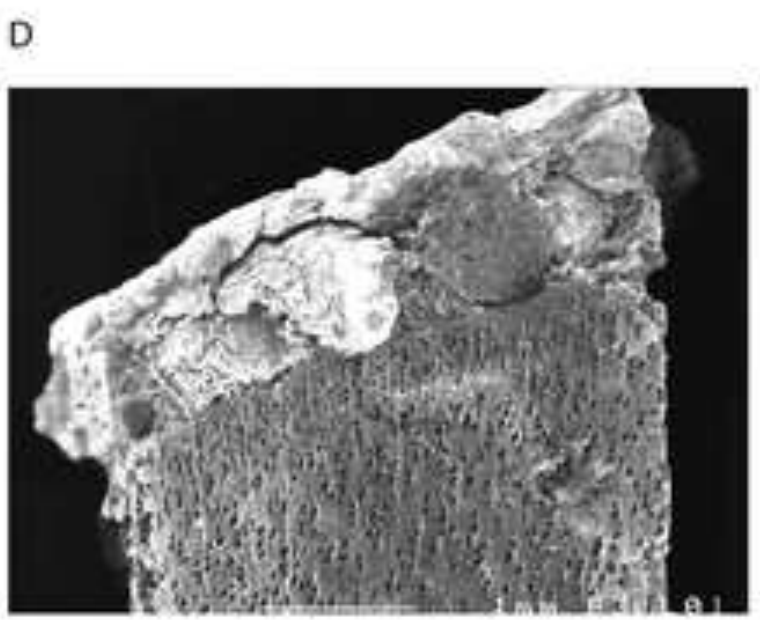

F

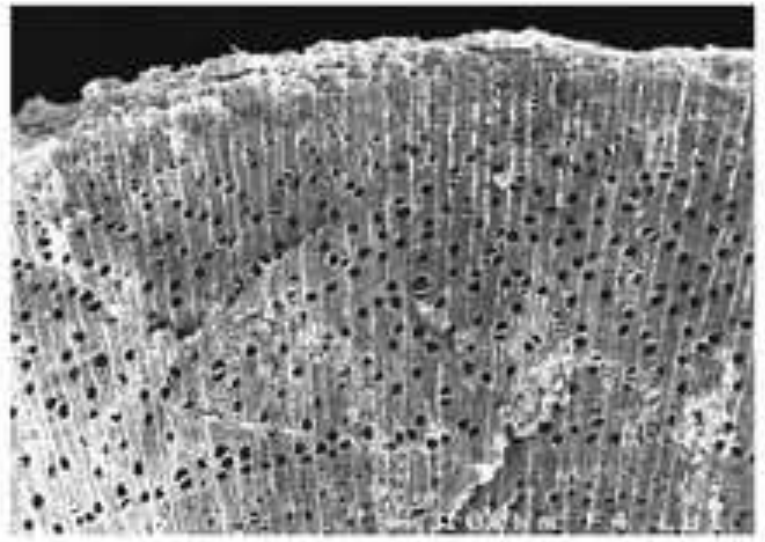

\section{Figure 6}




\begin{tabular}{|c|c|c|c|c|c|c|c|c|c|c|c|c|c|c|c|}
\hline & (Badatan: & $\begin{array}{l}\text { adiocarbon dating } \\
\text { tal, 2008; in peess) }\end{array}$ & $70 \%$ & $20 \%$ & $50 \% \frac{1}{1}$ & $10 \%$ & $\pi \%$ & $70 \%$ & $\overline{80 \%}$ & $\overline{20} \%$ & $\overline{30 \%}$ & $10 \%$ & $5 \%$ & $10 \%$ & No. \\
\hline \multirow{4}{*}{$\begin{array}{l}\text { Late } \\
\text { Bronze } \\
\text { Age }\end{array}$} & $\begin{array}{l}\text { T18 } \Delta 16 \\
\text { Pit }\end{array}$ & & 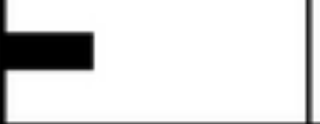 & & & & & & & & & & & & 186 \\
\hline & $\begin{array}{l}\text { T } 21 \Delta 6 \\
\text { Floor }\end{array}$ & Ca. $1370-1053 \mathrm{BC}$ & & & & $\bullet$ & & & 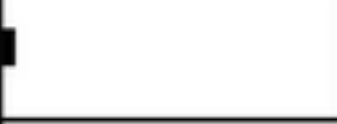 & ש & 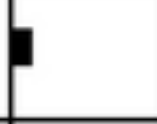 & & 1 & & 140 \\
\hline & $\begin{array}{l}\text { T } 21 \Delta 37 \\
\text { Pit }\end{array}$ & & & & • & & & & 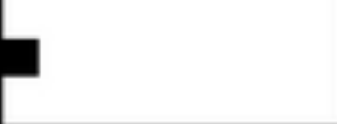 & & & & 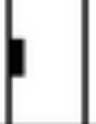 & & 150 \\
\hline & $\begin{array}{l}\text { T } 21 \Delta 54 \\
\text { Pit }\end{array}$ & & & & & & • & & 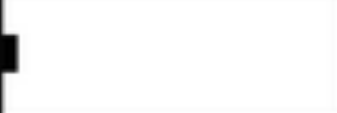 & 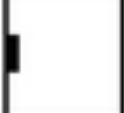 & & & 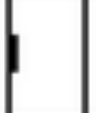 & & 100 \\
\hline \multirow{2}{*}{$\begin{array}{l}\text { Early } \\
\text { Bronze } \\
\text { Age }\end{array}$} & $\begin{array}{l}\text { T18 } \Delta 13 \\
\text { Floor }\end{array}$ & $\begin{array}{l}\text { ac. } 2899-2658 \mathrm{BC} \\
\text { ca. 2861-24908 BC }\end{array}$ & & a & $\bullet$ & & & & & & 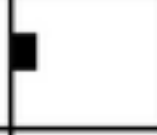 & 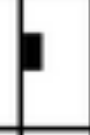 & & 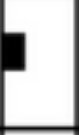 & 150 \\
\hline & $\begin{array}{l}\text { T18 } \Delta 32 \\
\text { Pit }\end{array}$ & C.3. $3101-2907 \mathrm{BC}$ & & & & $\bullet$ & & • & & $\bullet$ & & & $\bullet$ & $\bullet$ & 250 \\
\hline & Taxa & & & 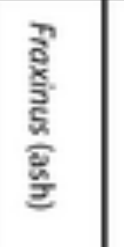 & 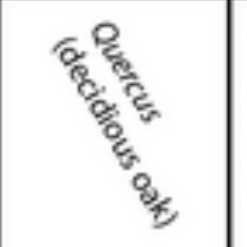 & 产 & 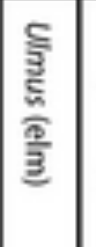 & 圜 & $\frac{\mathrm{E}}{\mathrm{E}}$ & 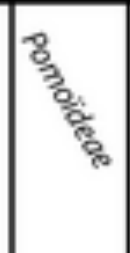 & 旁 & 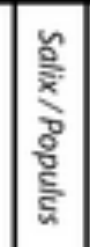 & 总 & 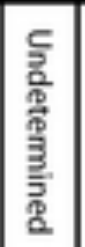 & \\
\hline
\end{tabular}



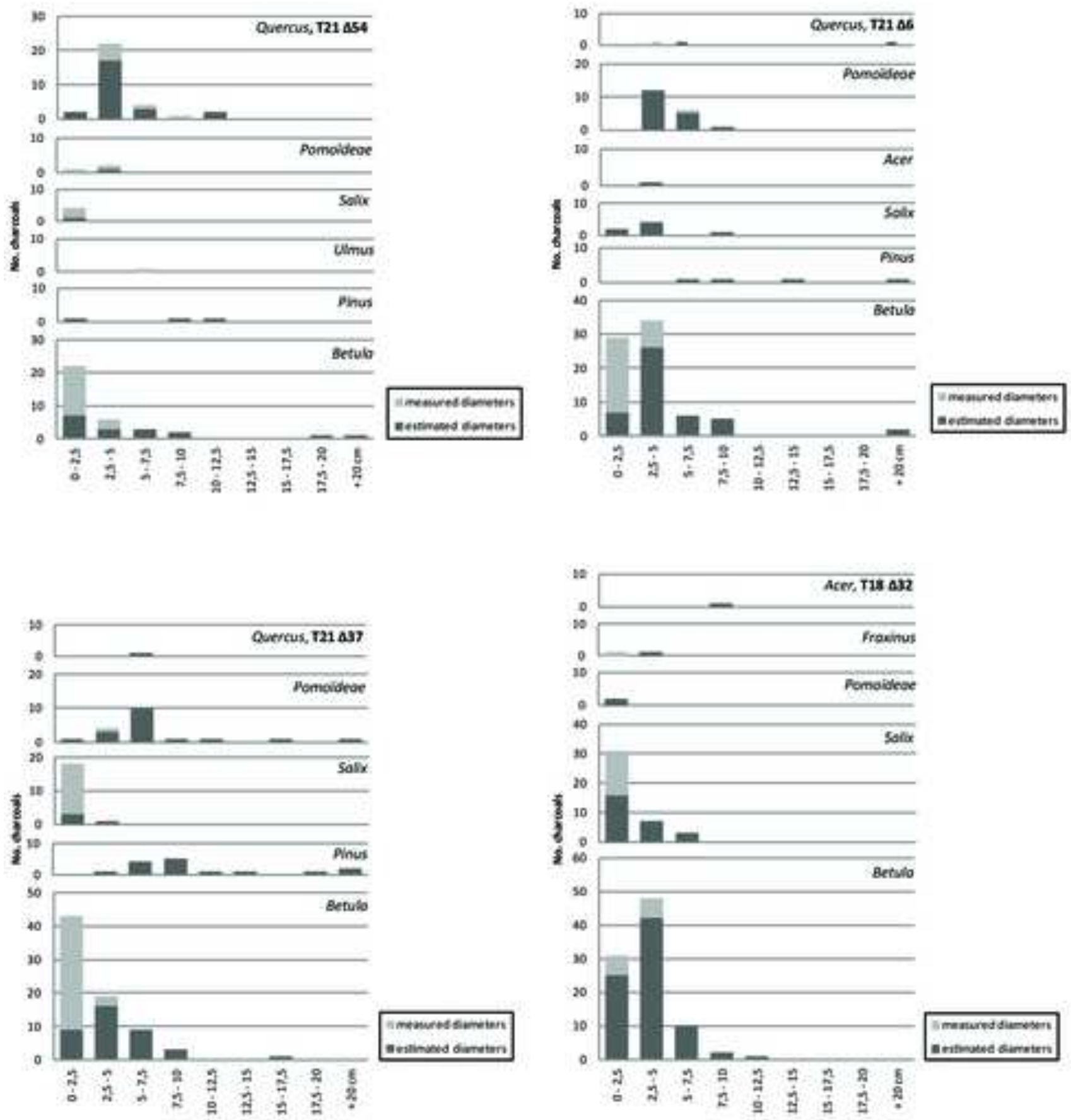

imenurbedsumeinen Gerilimued dimatim
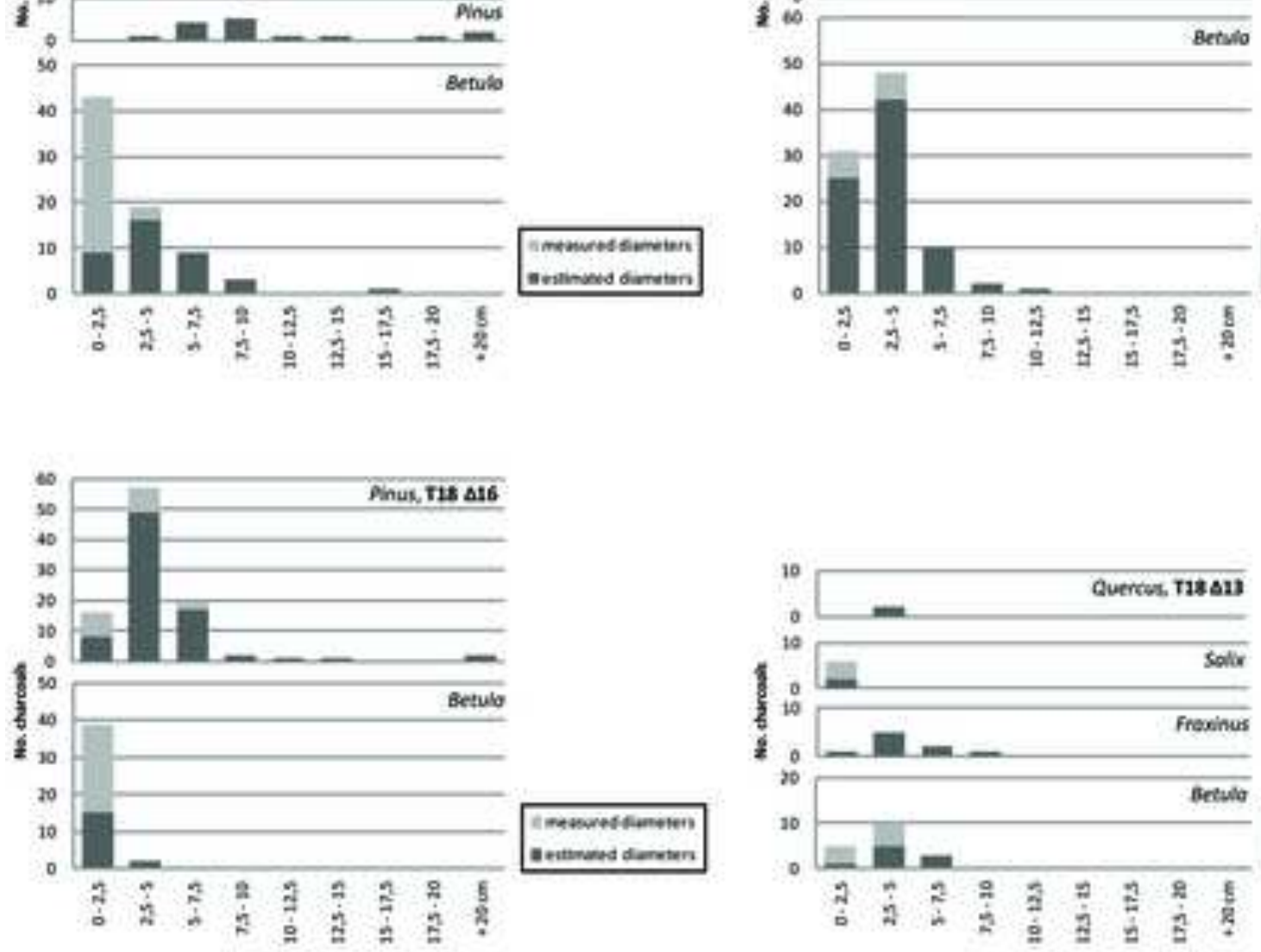

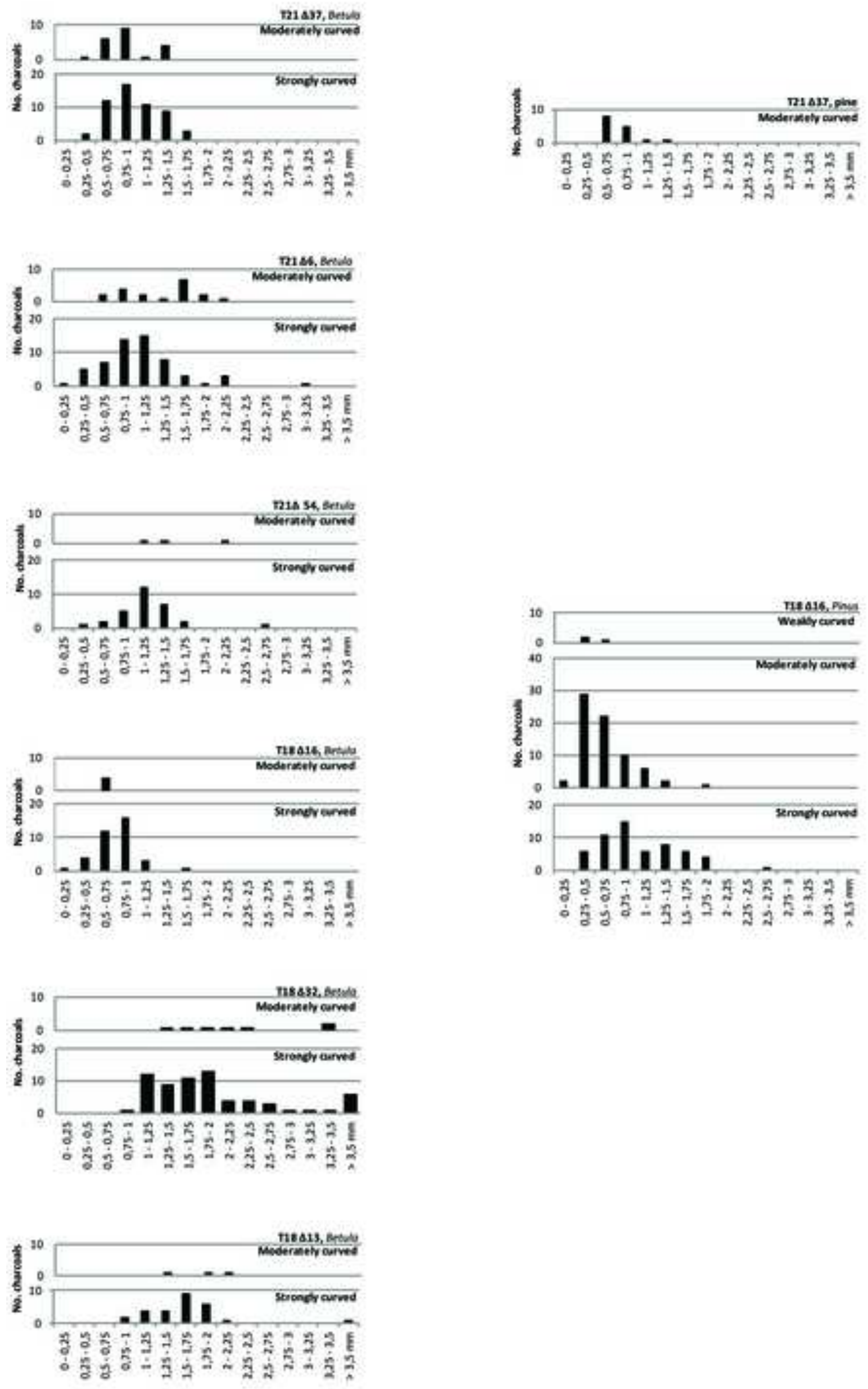


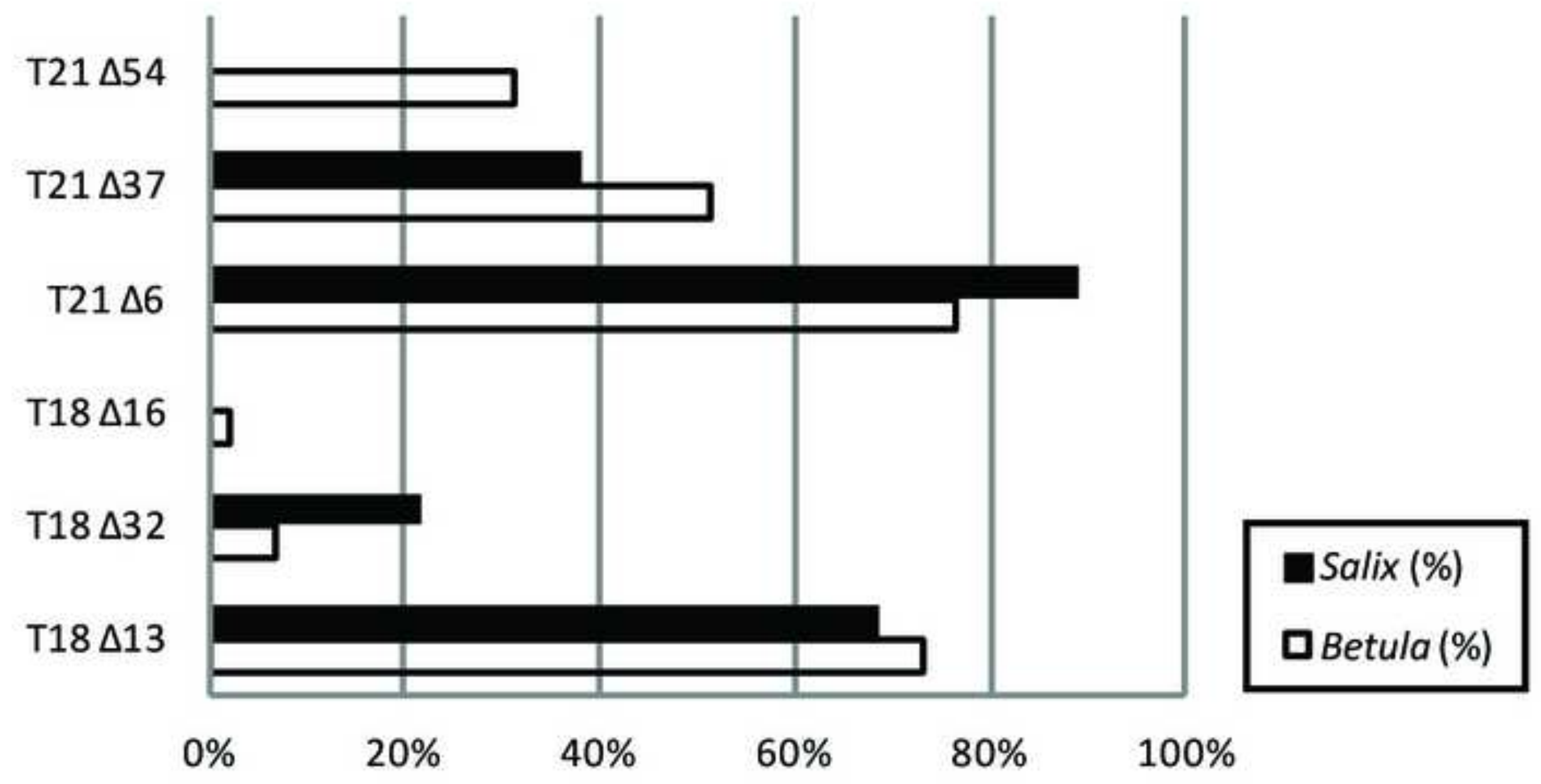


Quercus

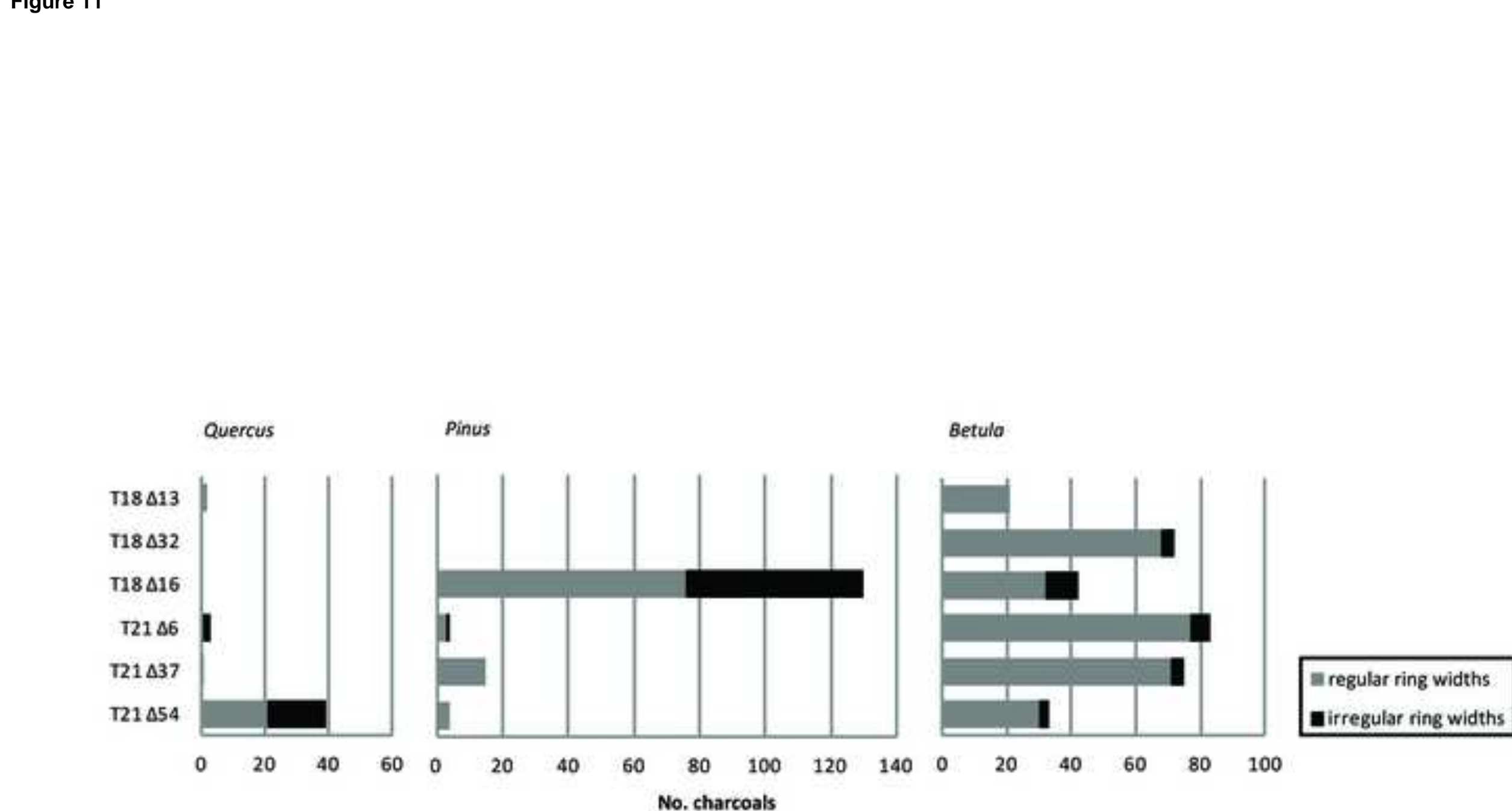

Pinus

No. charcoals

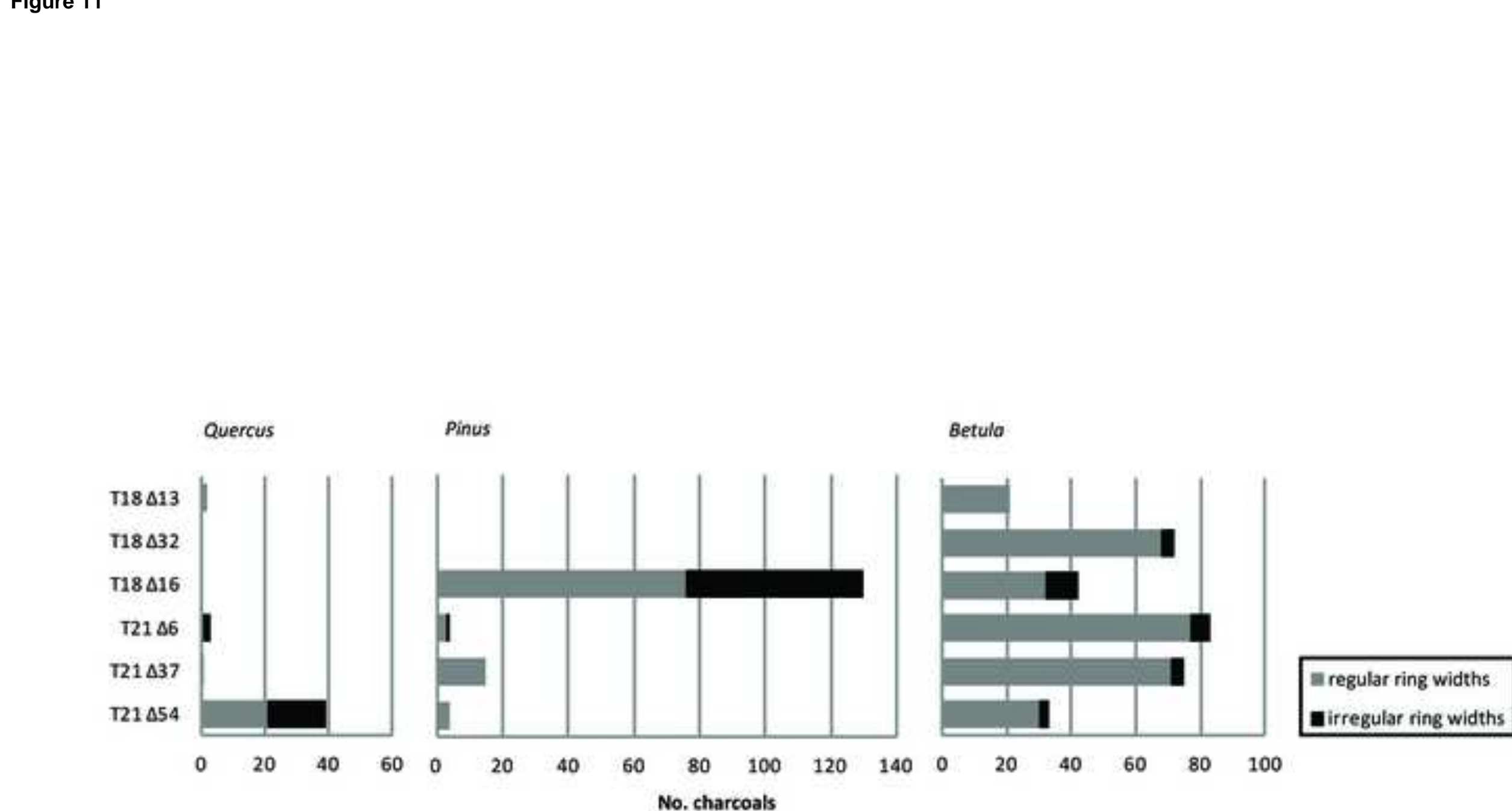

Betula

regular ring widths

- irregular ring widths

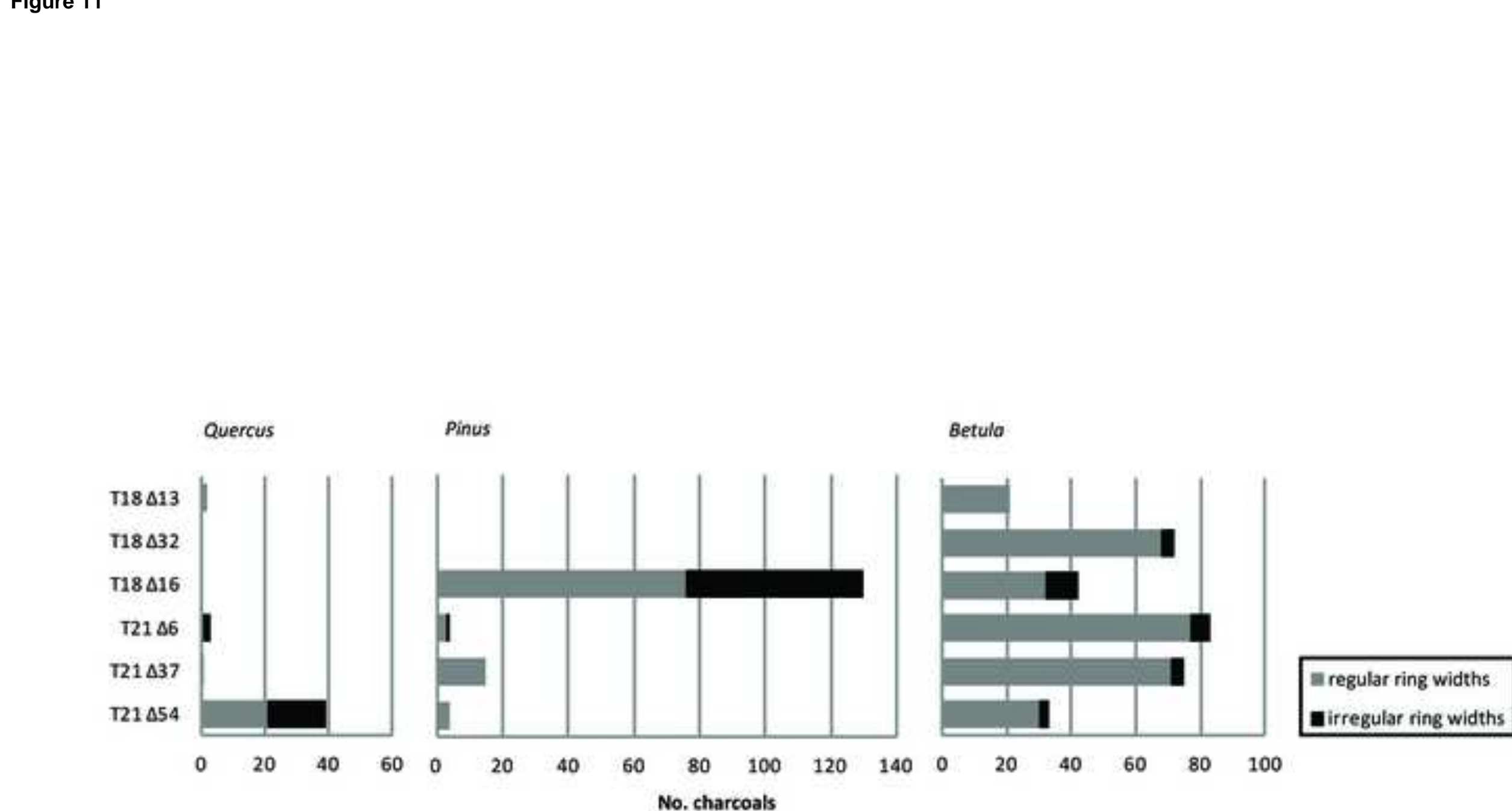



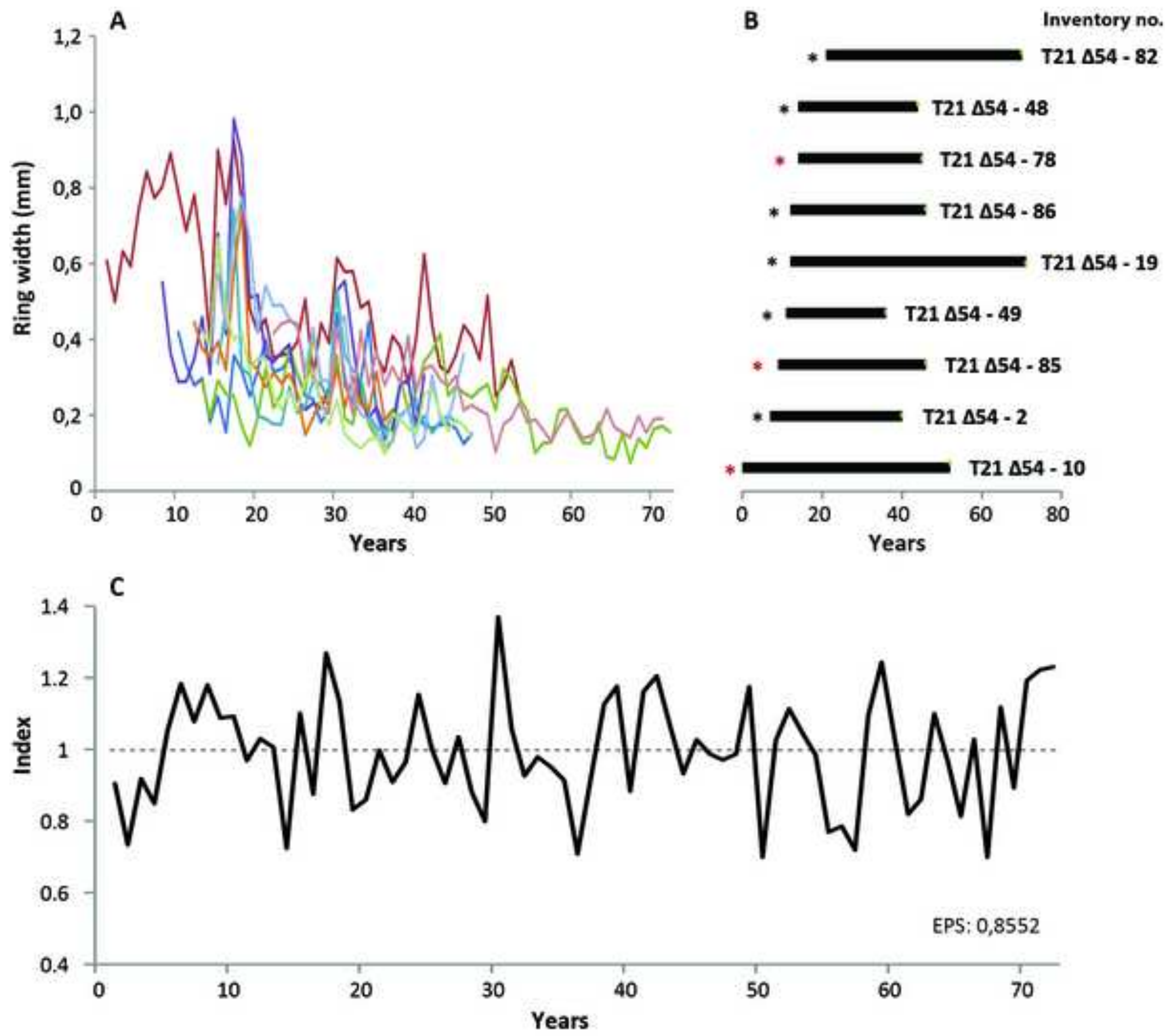


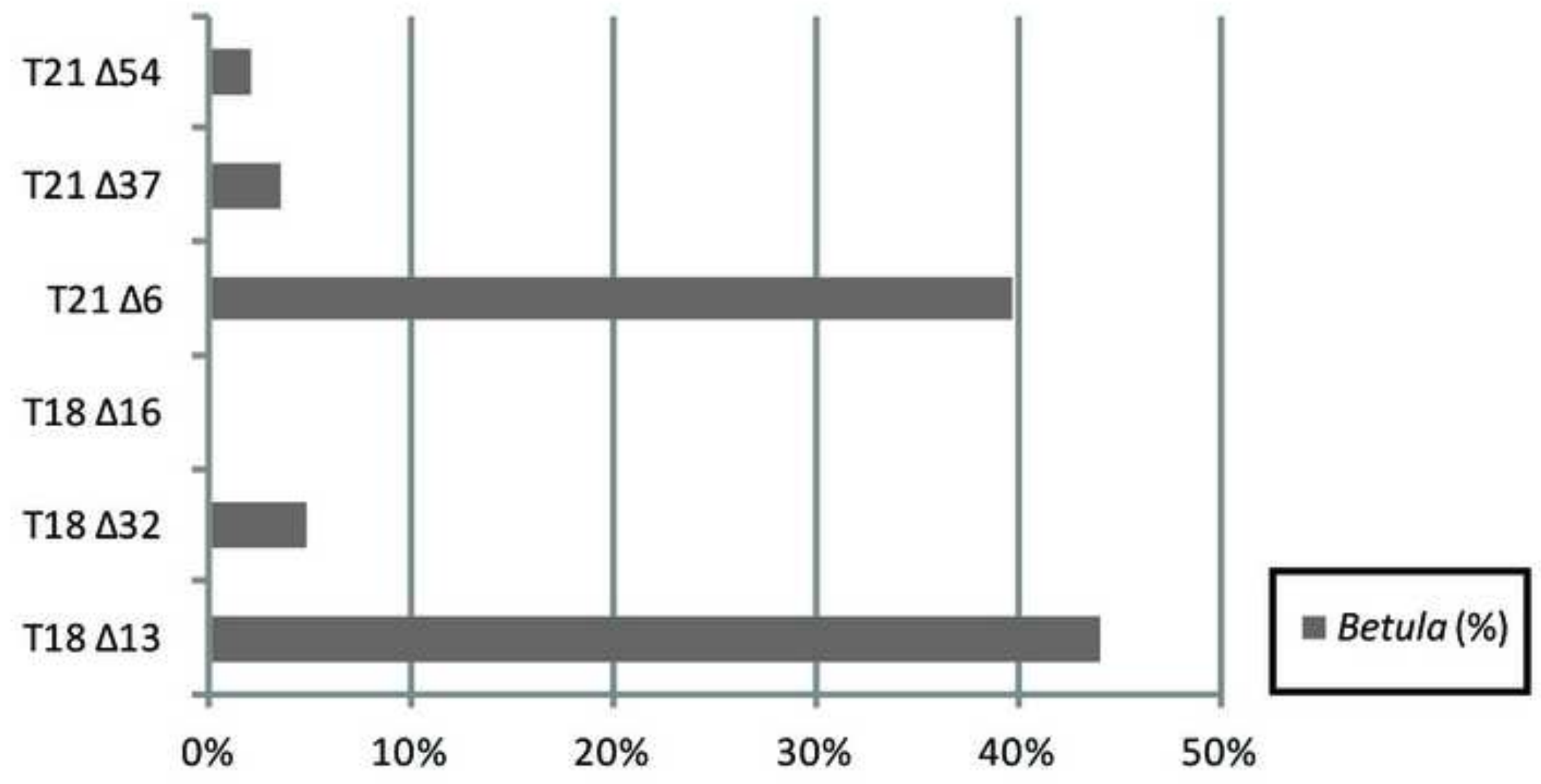



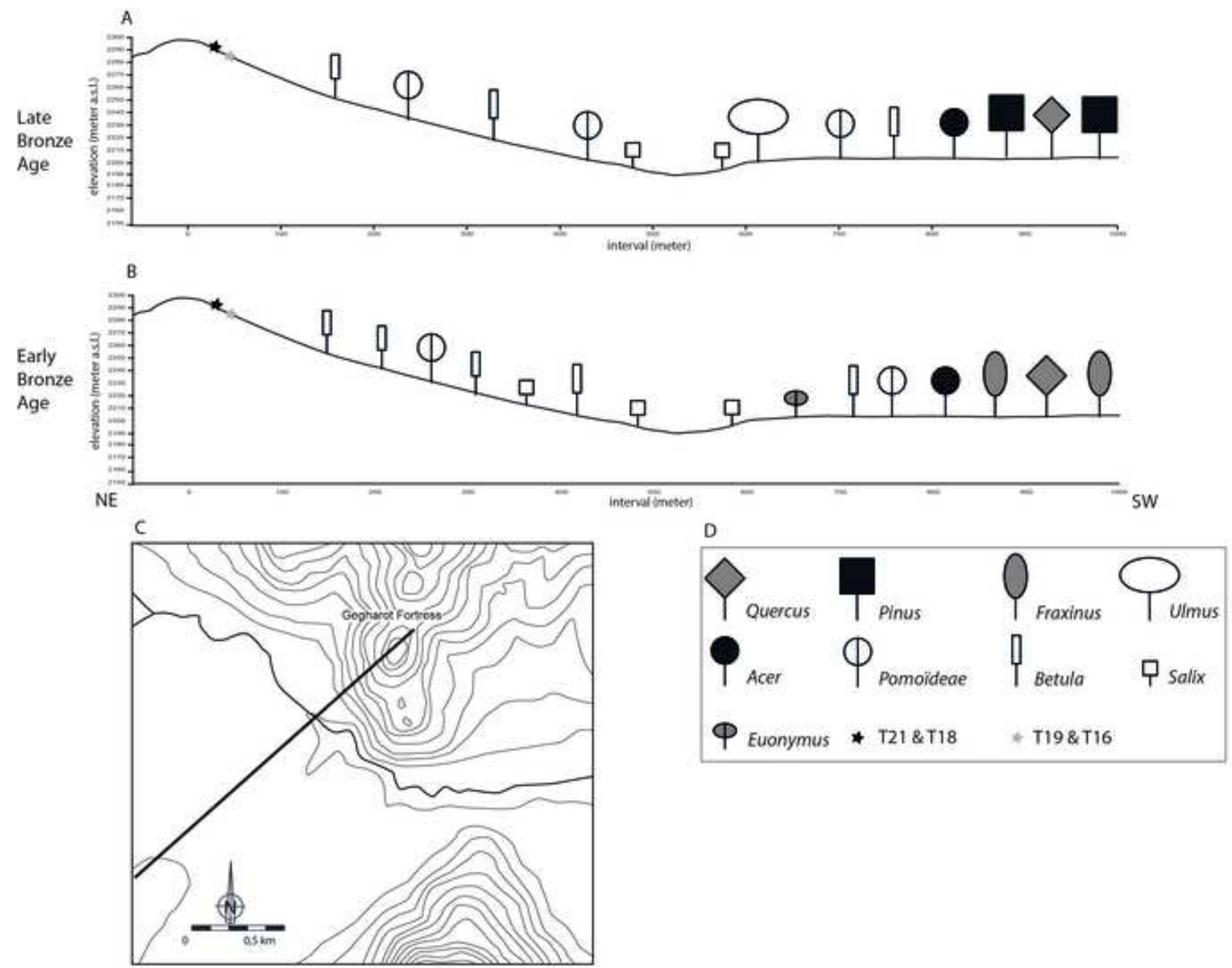